\title{
Desatando os nós do neoconstitucionalismo brasileiro
}

\author{
Vilian Bollmann ${ }^{1}$
}

\begin{abstract}
Sumário: Introdução. 1. Aspectos iniciais; 2. Os nós a serem desatados; 2.1. A formalidade do princípio do discurso; 2.2. A pretensão de veracidade e o processo litigioso; 2.3. O acordo final; 2.4. O corte epistemológico; 2.5. A Alienação no senso comum teórico dos juristas, 2.6. A ausência de metacritérios e o uso retórico dos processos interpretativos; 2.7. A subjetividade escondida na técnica da ponderação; 2.8. A omissão da distinção com as políticas ou diretrizes. 2.9. O uso de expressões retóricas; 3. Uma proposta de desate; 3.1. A rejeição da hipótese cínica; 3.2. Interdependência entre direito e política; 3.3. O direito como prática moral e política de resolução de conflitos; 3.4. O direito como (re)produtor de relações de poder; 3.5. Um realismo jurídico à brasileira, 3.6. Uma proposta de modelo teórico para um novo Constitucionalismo; Conclusão; Referências.
\end{abstract}

Resumo: O estudo aborda algumas insuficiências do modelo neoconstitucionalista brasileiro contemporâneo. São analisadas tanto sua base filosófica quanto algumas inconsistências na sua aplicação prática no cotidiano forense. A partir desta análise, busca-se apresentar um modelo complementar que, aliando aspectos do realismo jurídico e de outros ramos da ciência, compreenda o Direito como uma prática moral e política de solução de conflitos e tente descrevêlo com mais exatidão para prescrever ideais normativos de controle democrático do poder.

Palavras-chave: constitucionalismo; póspositivismo; realismo jurídico; Habermas; "critical legal studies".

\begin{abstract}
The study shows some shortcomings of the actual constitutional Brazilian model. It analyzes both their philosophical basics as some inconsistencies in its application by the judges. From this analysis, it attempts to present a complementary model that combine aspects of legal realism and other branches of science, understanding the law as a moral and political practice of resolving conflicts and trying to describe it with more accuracy to prescribe optimal standards of democratic control of power.
\end{abstract}

Keywords: constitutionallism; postpositivism; realism; Habermas; "critical legal studies".

\footnotetext{
1 Juiz Federal Substituto. Mestre em Ciência Jurídica pela em Ciência Jurídica pela Universidade do Vale do Itajaí - UNIVALI. Autor dos livros "Novo código civil: princípios, inovações na parte geral e direito intertemporal”, "Juizados Especiais Federais: comentários à legislação de regência" e "Hipótese de Incidência Previdenciária e temas conexos". Endereço eletrônico para contato: vilianbollmann@yahoo.com.br.
} 


\section{Introdução}

O Constitucionalismo ${ }^{2}$ sofreu diversas alterações no tempo, especialmente no que se refere à ampliação da esfera de atuação do Poder Judiciário. Ocorre que, superado o positivismo estrito, o chamado "póspositivismo" ou "neoconstitucionalismo" não trouxe, no Brasil, ainda, um verdadeiro discurso democrático sobre a decisão judicial. Da mesma forma que o uso retórico dos "métodos de interpretação" esconde uma "arbitrariedade judicial", o uso dos princípios como válvula de escape para inserir os valores do juiz no discurso de sua decisão, pode provocar o mesmo resultado.

Se por um lado o modelo neoconstitucionalista se amolda melhor à prática jurídica contemporânea do que às explicações positivistas ou jusnaturalistas, ele ainda é insuficiente, seja para descrever como é o direito (pretensão descritiva), seja para traçar prescrições sobre como o direito deveria ser (pretensão normativa).

Além disso, observa-se que a prática forense e doutrinária reflete uma incorporação incompleta da teoria que está nos fundamentos do neoconstitucionalismo. Essa introdução parcial também é problemática em razão da falta de adaptação à características próprias da evolução política do Brasil. Portanto, não se fará, aqui, estudo fundado em teorias formais despidas de contato com a realidade e nem descrições analíticas do postulado (ou princípio) da proporcionalidade.

Por outro lado, não se pretende esgotar o assunto e nem tampouco trazer soluções mágicas, que, por evidente, não existem. Busca-se, sim, trazer à luz alguns dos obstáculos que existem para o "neoconstitucionalismo" no plano político e moral dos juristas brasileiros, assim como evidenciar a ocultação das razões que possam estar por

2 Constitucionalismo é, simultaneamente, uma teoria ou ideologia e um movimento que, sob a influência do Iluminismo e do Contratualismo, estrutura a organização política a partir do princípio do governo limitado como indispensável para a garantia dos direitos. Apresenta-se como uma teoria normativa da política contra o absolutismo, pregando que o Direito limita o poder Estatal. Logo, a liberdade, como sentido axiológico inicial do constitucionalismo, fundamentou a ideia da Constituição como a lei para reger o Estado. Tem como traços marcantes a Organização do Estado e a Limitação do seu poder (CANOTILHO, José Joaquim Gomes. Direito constitucional e teoria da constituição. 4. ed. Coimbra: Almedina, 1999, p. 51). 
detrás das estratégias de poder existentes. Como diz o filósofo e jurista nicaraguense Alejandro Caldera, é comum, na América Latina, dizer o que não se faz e fazer o que não se diz. ${ }^{3}$ Apresentar possíveis inconsistências e trazê-las ao exame não é tarefa que se esgota em poucas páginas, mas representa uma tentativa de aprimorar o conhecimento sobre o tema, modificando o curso da trajetória que, se mantidas as condições atuais, pode levar a um formalismo abstrato que, destituído de fundação concreta, permitirá a arbitrariedade travestida de racionalidade.

Neste processo, é possível apontar algumas direções, ainda que elas possam trazer contradições entre si e não formem um todo sistemático. A questão não é achar uma resposta definitiva (objetivo que seria no mínimo ingênuo e no limite pouco democrático e arbitrário ${ }^{4}$ ), mas sim a possibilidade de formação de um novo discurso para que outras soluções sejam buscadas com inclusão de aportes oriundos de fora do círculo fechado dos juristas.

O fio condutor do presente trabalho é que a perspectiva jurídica não consegue, por si só, produzir soluções práticas, especialmente quando passa a focar a Constituição e a prática jurídica como objetos alienados dos seus partícipes, ignorando o jogo de poder que lhes constrói e que direciona a aplicação cotidiana.

Nunca é demais lembrar que a busca da verdade origina-se da distinção entre ignorância (não saber que não sabe) e incerteza (saber que não sabe). A partir daí, é possível abandonar certas crenças e emissões do imaginário social. Este abandono pode resultar em dois tipos diferentes de conduta. Uma, a simples busca de novas crenças, formando-se uma certeza. Outra, a dúvida metódica, ou seja, vencer o dogmatismo e a crença de que o mundo existe e é como percebemos, para depois de um momento de estranhamento, continuamente investigar os fatos e teorias e só aceitar aquilo que, submetido à crítica, revelar-se induvidoso. ${ }^{5}$

Para isso, após: 1) uma breve exposição das linhas mestras do movimento neoconstitucional, que aparentemente começa a tomar o

3 CALDERA, Alejandro Serrano. Razão, direito e poder: reflexões sobre a democracia e a política. Ijuí: Unijuí, 2005, p. 75-77.

4 Ao revés, é natural e previsível que diversas das propostas aqui apresentadas sejam criticadas e, com isso, aperfeiçoadas ou até mesmo rejeitadas.

5 CHAUÍ, Marilena. Convite à filosofia. São Paulo: Ática, 1997, p. 90-95. 
caráter de discurso hegemônico, incluindo sua base filosófica; 2) buscarse-á apresentar alguns de seus pontos problemáticos mais evidentes para, em seguida; 3 ) refletir sobre algumas sugestões de aprimoramentos.

\section{Aspectos iniciais}

O Constitucionalismo passa, atualmente, por um estágio especial, que é identificado por alguns como "pós-positivismo" e por outros como "neoconstitucionalismo", gerando um certo senso teórico comum dos constitucionalistas. ${ }^{8} \mathrm{O}$ neoconstitucionalismo funda-se, do ponto de vista metodológico-formal sob as premissas da normatividade, superioridade e

6 Por pós-positivismo, entende-se "o movimento crítico, que encerra o predomínio da dogmática jurídica tradicional, [...] abre-se [...] duas vertentes. Uma delas é desenvolvida por autores que buscam na moral uma ordem valorativa capaz de romper os limites impostos pelo ordenamento jurídico positivo [...] amparam-se, fundamentalmente, na argumentação capaz de legitimar as posições assumidas pelos intérpretes [...] os nomes de Chaïm Perelman, Ronald Dworkin, Jürgen Habermas e Robert Alexy [...]. Em outra banda, encontram-se autores que abraçam o pragmatismo, como [...] Friedrich Muller, Peter Habërle e Castanheira Neves" (CAMARGO, Margarida Maria Lacombe. Hermenêutica e Argumentação: uma contribuição ao Estudo do Direito. 3. ed. ver. atual. Rio de Janeiro: Renovar, 2003, p. 136-138). Para Bonavides, o pós-positivismo é uma terceira fase que corresponde aos momentos constituintes das últimas décadas em que os princípios passam a ser considerados a base normativa dos sistemas constitucionais, especialmente a partir dos estudos de Boulanger, Dworkin e Alexy (BONAVIDES, Paulo. Curso de Direito Constitucional. 11. ed. São Paulo: Malheiros, 2001, p. 237-240).

7 BARCELLOS, Ana Paula de. Neoconstitucionalismo, Direitos Fundamentais e Controle de Políticas Públicas. Revista de direito administrativo, v. 240, abr.jun. 2005, p. 82-83.

8 A doutrina constitucionalista brasileira já explora essa orientação "pós-positivista", podendo-se citar, dentre outros: ÁVILA, Humberto. Teoria dos princípios: da definição à aplicação dos princípios jurídicos; BARCELLOS, Ana Paula de. A eficácia jurídica dos princípios constitucionais: o princípio da dignidade humana. Rio de Janeiro: Renovar, 2002; BARROSO, Luís Roberto. Interpretação e aplicação da constituição: fundamentos de uma dogmática constitucional transformadora. 3. ed. rev. e atual. São Paulo: Saraiva, 1999; BONAVIDES, 2001; BORGES, Alexandre Walmott, A ordem econômica e financeira da Constituição e os monopólios: análise das alterações com as reformas de 1995 a 1999; ESPÍNDOLA, Ruy Samuel. Conceito de princípios constitucionais: elementos teóricos para uma formulação dogmática constitucionalmente adequada. São Paulo: RT, 1999; GRAU, Eros Roberto, Ensaio e discurso sobre a Interpretação/Aplicação do Direito; PIOVESAN, Flávia; VIEIRA, Renato Stanziola. A Força normativa dos Princípios Constitucionais Fundamentais: a Dignidade da Pessoa Humana; SARMENTO, Daniel, A ponderação de interesses na Constituição Federal; SILVA, Virgílio Afonso da, A constitucionalização do direito: os direitos fundamentais nas relações entre particulares. 
centralidade da Constituição; e, do ponto de vista material, na incorporação explícita de valores e opções políticas no texto constitucional e por uma expansão dos conflitos entre as opções normativas e filosóficas dentro do próprio sistema constitucional. Isto é: dentro do sistema constitucional convivem diferentes pretensões normativas, próprias de uma comunidade plural, que se chocam e se colidem, seja no plano de aparentes antinomias entre comandos constitucionais, seja na discussão sobre o próprio papel da Constituição no conflito entre substancialismo e procedimentalismo. ${ }^{9}$

A ideia de princípio e a sua aplicação no plano jurídico sofreu três fases históricas. ${ }^{10} \mathrm{Na}$ primeira, chamada de jusnaturalista, a juridicidade dos princípios é basicamente nula e duvidosa, tendo apenas uma conotação ético-valorativa. A segunda, puramente positivista, identificou os princípios como meras pautas programáticas supralegais, carentes ainda de uma normatividade. A terceira, inserida no chamado pós-positivismo, identifica, a partir da hegemonia das Constituições, a plena normatividade dos princípios, que podem, por conseguinte, criar obrigações legais. ${ }^{11}$

Vale mencionar, porém, que há pelo menos três tipos de teorias sobre a distinção entre princípios e regras: 1) as que visualizam uma dicotomia clara e forte entre regras e princípios; 2) outras que reconhecem a diferença, mas entendem que ela seria fraca e débil; e, por fim, 3) aquelas que não reconhecem diferenças entre regras e princípios. ${ }^{12}$

9 BARCELLOS, 2005, p. 83-88.

10 BONAVIDES, 2001, p. 228-238. Confira-se, também: BORGES, Alexandre Walmott. A ordem econômica e financeira da Constituição e os monopólios: análise das alterações com as reformas de 1995 a 1999, p. 54-56.

11 Para uma análise mais aprofundada sobre o conceito de princípios na doutrina brasileira, com ampla pesquisa acerca da configuração estrutural feita por diversos autores, vide: Espíndola (1999). Para ele, é possível identificar os seguintes pontos teóricos pacíficos, dentre outros; 1) há distinção entre princípios e regras, sendo ambos espécies de normas jurídicas; 2) os princípios constitucionais servem tanto como critérios de interpretação jurídica quanto para impor limites materiais ao poder constitucional reformador; 3 ) existem princípios constitucionais implícitos; 4) as regras constitucionais são especificações dos princípios e estes têm seu sentido dado não somente pelo texto em que são previstos, mas também pelos seus desdobramentos; porém, ele identifica certas insuficiências, como: a) ausência de classificações dos princípios - exceção feita aos autores Barroso e Sampaio Dória -; b) uma tendência de hierarquizar os princípios entre si; c) a ausência da delimitação de uma metódica de aplicação dos princípios (ESPÍNDOLA, 1999, p. 247-252).

12 SILVA, Virgílio Afonso da. A constitucionalização do direito: os direitos fundamentais nas relações entre particulares, p. 30-32. Vide, também: ÁVILA, Humberto. Teoria dos princípios: da definição à aplicação dos princípios jurídicos, p. 26-31. 
Aparentemente, porém, a distinção mais aceita na doutrina é a proposta por Dworkin. Nela, a diferença entre regras e princípios é de natureza lógica e derivada da contingência de sua aplicação. ${ }^{13}$ Enquanto as regras são aplicáveis à maneira do tudo-ou-nada, os princípios possuem uma dimensão de peso. Eles enunciam razões que conduzem a uma direção, sem especificar qual a decisão particular a ser tomada. ${ }^{14}$ Embora utilize a categoria princípio de forma genérica por toda a sua obra, ${ }^{15}$ Dworkin afirma que há distinção entre princípios e políticas. As políticas determinam padrões de conduta em função de um objetivo que levará a uma melhoria da vida comunitária sob algum aspecto (econômico, social ou político), estabelecendo um objetivo coletivo. Os princípios, por sua vez, apontam um padrão de conduta em função de exigências de justiça ou equidade que estabelecem um direito de um indivíduo ou de um grupo. ${ }^{16}$

Outra concepção bastante aceita no senso comum dos constitucionalistas brasileiros é a de Alexy, que, na busca da formação de uma teoria para a dogmática dos direitos fundamentais, traça, como seu instrumento principal, uma distinção entre dois tipos de normas, os princípios e as regras. Afirma que, tanto aqueles quanto essas, representam normas, não só porque dizem o que deve ser, mas também porque podem ser expressos por expressões deônticas, como ordens, permissões e proibições. ${ }^{17}$ Para ele, o ponto fundamental para a distinção é a dinâmica de sua aplicação, vale dizer, os princípios são cumpridos em diferentes níveis, conforme as possibilidades jurídicas e fáticas; as regras, por sua vez, têm aplicabilidade mais restrita, ou seja, ou são cumpridos ou não são. Enquanto os princípios configuram normas que ordenam que algo seja realizado na melhor forma possível, como mandados de otimização, as regras são normas que só podem ser cumpridas mediante aplicação direta na forma exata como ela exige. A distinção seria de qualidade e não

13 DWORKIN, Ronald. Levando os Direitos a sério. São Paulo: Martins Fontes, 2002, p. 39.

14 DWORKIN, 2000, p. 39-43.

15 Fato admitido pelo próprio autor, confira-se: DWORKIN, 2000, p. 36.

16 DWORKIN, 2000, p. 36, 129-132, 141-142. Esta mesma distinção é feita em DWORKIN, Ronald. Uma questão de princípio. 2. ed. São Paulo: Martins Fontes, 2005, p. 6-8.

17 ALEXY, Robert. Teoria de los derechos fundamentales. Madrid: Centro de Estúdios Políticos y constitucionales, 2002 ALEXY, Robert. Teoria de los derechos fundamentales. Madrid: Centro de Estúdios Políticos y constitucionales, 2002, p. 81-83. 
de grau, havendo uma dicotomia mutuamente excludente, ou seja, ou a norma é regra ou é princípio; estes definem um comando de otimização; aqueles, um comando de definição. ${ }^{18}$

Em razão desta diferença fundamental, o fenômeno da incompatibilidade normativa é solucionado de forma distinta para esses tipos de normas. Os princípios, quando em colisão, compatibilizam-se por uma preponderância específica na dimensão do peso, isto é, num caso particular, sob certas circunstâncias, um deles cede; em outro caso, sob outras circunstâncias, o outro pode prevalecer. As regras, por sua vez, quando em conflito, só admitem solução mediante inserção de uma cláusula de exceção ou da declaração de invalidade de uma delas. Os conflitos entre regras são resolvidos no plano da validade, mas as colisões entre princípios são resolvidas na dimensão do peso. ${ }^{19}$ As incompatibilidades entre princípios e regras, quando previstos em diplomas de idêntica hierarquia (por exemplo, se ambos estão previstos na Constituição), são resolvidas em favor destas. Ele justifica esta escolha porque as ordens dadas pelas regras precedem as alternativas que poderiam decorrer dos princípios, já que estes deixam muitas coisas por decidir. ${ }^{20}$

Para Alexy, porém, a determinação da relação específica de preponderância deve ser feita por um método que permita o controle racional do seu resultado; para isso, a preferência condicionada não pode ser feita intuitivamente, mas sim de acordo com um modelo de fundamentação. Em outras palavras, é necessário explicitar as razões da escolha feita e indicar os argumentos utilizados no percurso. Dessa forma, as ponderações feitas pela jurisprudência e as propostas de ponderação feitas pela doutrina produzem, com o tempo, uma rede de regras concretas derivadas da lei de colisão que representarão o objeto principal para a dogmática. Neste modelo, distingue-se o processo psíquico responsável pela escolha intuitiva do processo racional de determinação justificada da opção feita, utilizandose, dentre outros, cânones de interpretação, argumentos gerais ou mesmo os especificamente jurídicos. Há, portanto, uma correlação entre a teoria dos princípios e a teoria da argumentação jurídica. ${ }^{21}$

18 ALEXY, 2002, p. 86-87.

19 ALEXY, 2002, p. 87-89.

${ }^{20}$ ALEXY, 2002, p. 134.

${ }^{21}$ ALEXY, 2002, p. 157-159, 167-168. 
A base filosófica assumida por Alexy é a teoria da ação comunicativa de Habermas. Esta, por sua vez, é fundada na tese de que todo ato de fala é dirigido à compreensão mútua; logo, tem uma pretensão de verdade. ${ }^{22}$ Essa pretensão, porém, significa coisas diferentes conforme o tipo de ato de fala; assim: 1) nos atos de fala de constatação (narrar, afirmar, explicar, prever etc.), o sujeito pretende que seu enunciado seja verdadeiro; 2) nos atos reguladores (ordenar, exigir, aconselhar, reprimir), o falante pretende que aquilo que ele ordena seja correto; e 3) nos atos de fala representativos (revelar, descobrir, ocultar, admitir), pretende-se que aquilo que se exprime seja sincero. ${ }^{23}$

No cotidiano, essas pretensões são aceitas; porém, quando problematizadas, passa-se da ação comunicativa para o discurso, no qual o falante terá que dar razões ou fundamentos para que suas asserções sejam consideradas verdadeiras (discurso teórico) ou para que a ação indicada como norma seja a correta (discurso prático). ${ }^{24} \mathrm{O}$ discurso será, então, uma forma de "coação não coativa do melhor argumento", 25 para chegar numa situação ideal de fala, ou seja, situação em que a comunicação não é impedida por fatores externos e nem pela estrutura da própria comunicação, mediante distribuição simétrica das oportunidades de escolha e execução dos atos de fala. ${ }^{26}$ Nesta situação, todos os falantes têm direitos iguais; porém, ela representa mais um ideal (estado a cumprir) do que um critério seguro. ${ }^{27}$

Para Habermas, o direito é o moderno direito normatizado, que, contendo certas pretensões (de fundamentação sistematizada, de interpretação obrigatória e de imposição), é, simultaneamente, um sistema de saber (instituições e tradições jurídicas intersubjetivamente compartilhadas) e um sistema de ação; como tal, comunica-se com os

22 ATIENZA, Manuel. As razões do direito: teorias da Argumentação Jurídica. 3. ed. Trad. Maria Cristina Guimarães Cupertino. São Paulo: Landy, 2003, p. 161.

23 ATIENZA, 2003, p. 161.

24 ATIENZA, 2003, p. 162.

25 ATIENZA, 2003, p. 162.

26 ATIENZA, 2003, p. 163.

27 ALEXY, Robert. Teoria da argumentação jurídica: a teoria do discurso racional como teoria da fundamentação jurídica. 2. ed. Tradução de Zilda Hutchinson Schild Silva. Revisão técnica de Cláudia Toledo. São Paulo: Landy, 2005, p. 130-131. 
códigos especializados da administração (dirigida pelo poder) e economia (dirigida pelo dinheiro) por meio da linguagem..$^{28}$

Ele reconhece, contudo, que o cumprimento da lei é realizado por dois motivos, ou por uma estratégia relacionada às consequências da infração pelo descumprimento, ou pelo sentimento de que a lei deve ser cumprida. ${ }^{29}$ À validade social (aceitação fática das normas de direito) contrapõe-se a facticidade artificial (ameaça de sanção definida na lei). A legitimidade das regras decorre ou da sua origem por um processo legislativo racional ou da sua justificação a partir de pontos de vista pragmáticos, éticos ou morais..$^{30}$ No sistema jurídico, o processo legislativo assume a função de integração social, resgatando a ideia de que a pretensão de legitimidade de uma ordem decorre da força socialmente integradora de todos os cidadãos livres e iguais. A partir do momento em que o direito se despe de uma legitimação metafísica ou religiosa, a sua legitimidade depende de assegurar que todos os seus destinatários sintamse autores racionais daquelas normas. ${ }^{31}$

As normas de ação são fundamentadas pelo princípio do discurso: "são válidas as normas de ação às quais todos os possíveis atingidos poderiam dar seu assentimento, na qualidade de participantes de discursos racionais". 32

Da aplicação do princípio do discurso ao direito (princípio democrático) surgem três direitos fundamentais habermasianos dos sujeitos enquanto destinatários de leis: 1) o "direito à maior medida possível de iguais liberdades subjetivas de ação"; 2) os direitos de filiação (status) de um membro à associação voluntária; e 3) os direitos da possibilidade de postulação judicial de direitos. ${ }^{33}$ Em seguida, surgem os direitos dos sujeitos enquanto autores da ordem jurídica: 4) direitos de participação nos processos de formação da opinião e da vontade em igualdade de condições. ${ }^{34}$ Estes direitos políticos

${ }^{28}$ HABERMAS, Jürgen. Direito e democracia: entre facticidade e validade. Tradução de Flávio Beno Siebeneichler. Rio de Janeiro: Tempo Brasileiro, 1999, v. 1, p. 110-112.

29 HABERMAS, 1999, v. 2, p. 308.

30 HABERMAS, 1999, v. 1, p. 50.

31 HABERMAS, 1999, v. 1, p. 52-54.

32 HABERMAS, 1999, v. 1, p. 142.

33 HABERMAS, 1999, v. 1, p. 159.

34 HABERMAS, 1999, v. 1, p. 159-160. 
fundamentais implicam também em 5) direitos a condições sociais, técnicas e ecológicas de vida que sejam necessárias ao exercício dos quatro primeiros grupos de direitos. ${ }^{35}$

Passa-se, num segundo momento, a apresentar algumas das possíveis inconsistências do pós-positivismo praticado atualmente no Brasil (ou os "nós a serem desatados" no neoconstitucionalismo).

\section{Os nós a serem desatados}

\subsection{A formalidade do princípio do discurso}

O primeiro dos "nós" a serem desatados pelo neoconstitucionalismo refere-se à base de sua fundamentação filosófica, qual seja, a teoria habermasiana do discurso ideal como critério e princípio de legitimação.

Isso porque a situação ideal de fala habermasiana funciona para seres formalmente iguais, mas não para pessoas materialmente desiguais. A sua teoria, fundada na teoria dos atos da fala, ${ }^{36}$ busca construir uma pragmática universal. ${ }^{37}$

35 HABERMAS, 1999, v. 1, p. 160.

36 A teoria dos atos da fala iniciou-se na obra póstuma "Quando dizer é fazer" (how to do things with words) de Austin, publicada em 1972. Um ato de fala é uma ação que se realiza dizendo algo. Austin distingue os constatativos (uso da fala para descrever algo) ou performativos (uso para realizar), ou seja, dando ênfase na pragmática da linguagem, há duas dimensões dos enunciados, a constatativa (descreve) e a performativa (ato não linguístico); a linguagem é ação. Porém, ao perceber que mesmo um ato constatativo tem uma dimensão performativa (a realização de uma descrição), Austin passa a distinguir três dimensões da significação: (1) atos locucionários, dimensão estritamente ligada às regras gramaticais das palavras e sentenças, representando a expressão de um enunciado com um determinado significado; (2) atos ilocucionários, é o que se faz ao se dizer algo, representa o núcleo performativo do ato da fala que constitui o tipo de ato; e (3) atos perlocucionários, as consequências ou efeitos decorrentes do ato de fala em relação às demais pessoas nos seus sentimentos e pensamentos (ALEXY, 2005, p. 76-80; DUTRA, Delamar José Volpato. Razão e consenso em Habermas: a teoria discursiva da verdade, da moral, do direito e da biotecnologia. Florianópolis: Editora da UFSC, 2005, p. 44-49; MARCONDES, Danilo. A pragmática na filosofia contemporânea. Rio de Janeiro: Jorge Zahar ed., 2005a, p. 16-19. STRECK, Lênio Luiz. Hermenêutica jurídica e $(m)$ crise: uma exploração hermenêutica da construção do Direito. 5. ed. Porto Alegre: Livraria do Advogado, 2004, p. 167-169).

37 Ao contrapor a dialética do trabalho (relação entre o indivíduo e a natureza para a subsistência daquele) às dialéticas da moral (interação entre as subjetividades) e da 
Segundo Dutra, Habermas responde a seis objeções céticas, que se sucedem (uma dependendo da resolução da anterior): 1) "inexistência de fenômenos morais"; 2) a objeção de que "as proposições morais não admitem uma pretensão de validade análoga à verdade"; 3) "a impossibilidade de deduzir racionalmente a pretensão de validade"; 4) a "indagação da fundamentação do princípio da universalização" ou "o problema do Trilema de Münchhausen"; 5) a "negação ou recusa ao jogo da argumentação" e 6) a "acusação do formalismo vazio". ${ }^{38}$

A resposta ao ítem 6) é dada por Habermas com o argumento de que a contradição performativa ${ }^{39}$ só pode fundamentar o princípio da

linguagem (inerente aos processos de simbolização), Habermas iniciou o estudo daquilo que daria origem à Teoria da Ação Comunicativa. Ele diferencia a racionalidade instrumental (ação estratégica) da primeira dialética da racionalidade comunicativa das outras duas. A ação estratégica é a ação orientada para o êxito, regida pela lógica da dominação, na qual os planos são feitos para influenciar, não envolvendo assentimento ou dissentimento. A ação comunicativa orienta-se para a compreensão intersubjetiva que é melhor alcançada pela ausência de barreiras de comunicação. Para Habermas, a racionalidade instrumental, que define os fins e meios para obtê-los, deveria estar subordinada à racionalidade comunicativa. As questões ético-políticas surgem quando se discutem os fins e as preferências. A comunicação racional terá a tarefa de presidir a justificação das regras práticas da ação; para isso, deve observar certos pressupostos na formulação dos argumentos: a identidade da língua utilizada e a igualdade entre os participantes. Habermas buscará as condições para um discurso ideal a partir de Wittgenstein, Austin, Searle, Grice e Apel. A Teoria da Ação Comunicativa visa a estabelecer as condições de possibilidade de uma comunicação cuja universalidade decorrerá de quatro condições ou pretensões de uma situação ideal de discurso: 1) sinceridade (ainda que um falante tente mentir, ele buscará fazê-lo dando a aparência de verdade), 2) veracidade, nos atos de fala que expressam intenções ou atitudes do falante (atos de fala representativos), que só pode ser reconhecida pelos atos do próprio falante; 3 ) inteligibilidade, que se apresenta em qualquer ato de fala, sendo uma condição da comunicação; e 4) justificabilidade (condições necessárias para que o ato do falante seja bem-sucedido, tal como competência para delegar um ato ou conhecimento para informar um dado) (ALEXY, 2005, p. 124; ATIENZA, 2003, p. 206; DUTRA, 2005, p. 44; FARALLI, Carla. A filosofia contemporânea do direito: temas e desafios. Tradução de Candice Premaor Gullo. São Paulo: Martins Fontes, 2006, p. 15; HABERMAS, 1999, v. 1, p. 200-203; MARCONDES, 2005a, p. 35-40).

38 DUTRA, 2005, p. 164-187.

${ }^{39} \mathrm{O}$ argumento da autocontradição performativa, elaborado por Apel, ocorre quando uma negativa cética contém, em si mesma, a negação daquilo que pretende provar, isto é, ao argumentar negando o valor da argumentação, o ato de fala performativo acaba por se autonegar. A negativa de autocontradição implica que quem nega o princípio do discurso implicitamente o aceita, pois pretende o reconhecimento do que diz (a negativa); logo, para que tenha algum sentido, a negativa implica o reconhecimento positivo. Por isso, 
universalização; a fundamentação das normas com conteúdo é uma tarefa histórica e fática; ele é, portanto, necessariamente formal e processual. Por isso, o filósofo moral só pode fornecer um procedimento fundamentado de resolução das pretensões normativas; seu papel, enquanto especialista, é o de colaborar. É impossível que ele forneça as regras materiais mediante um monólogo de si para si, pois uma norma só será justificada se puder ser universalizada e ninguém consegue universalizar, algo a partir de si mesmo. Isso depende de um processo argumentativo real. ${ }^{40}$

Ocorre, porém, que a situação ideal de fala pressupõe uma igualdade formal entre os falantes. Na prática, contudo, esta igualdade de armas não existe, senão em situações excepcionais. Com efeito, é possível imaginar como igual um diálogo entre uma pessoa semialfabetizada e o Estado ou uma grande corporação? Da mesma forma, é possível qualificar como justiça procedimental perfeita a situação de um conflito argumentativo entre a população africana mais pobre e um país europeu? Estes questionamentos revelam que a base da igualdade formal do discurso habermasiano requer, no mínimo, algum tipo de mecanismo que: 1) considere a desigualdade material como algo real e 2) permita a redução da assimetria de poder, tanto quanto possível. Logo, é necessário explicitar, no mundo concreto, como a "coerção sem coerções" opera.

É bem verdade que Habermas reconhece a necessidade de a sociedade civil neutralizar a divisão desigual de posições sociais, como forma de assegurar o poder comunicativo em face do poder social (medida da possibilidade de um ator impor interesses próprios em relações sociais mesmo contra a resistência de outros). ${ }^{41}$ Porém, ao distinguir o discurso de fundamentação na criação de leis do discurso de aplicação - com a consequente separação entre legislativo e judiciário e pela assunção do princípio da ligação da justiça ao direito vigente $-{ }^{42}$ Habermas transfere 0

não se pode contestar a argumentação sem argumentar, incorrendo-se na autocontradição performativa (DUTRA, 2005, p. 89, 174-176).

40 DUTRA, 2005, p. 181-187.

41 HABERMAS, 1999, v. 1, p. 218-219.

42 HABERMAS, 1999, v. 1, p. 215-216. Para ele, “[...] a fim de impor suas decisões - e a execução do direito - a justiça apela para os meios de repressão do aparelho do Estado, passando a dispor, ela mesma, de um poder administrativo. Por esta razão, a justiça precisa estar separada da legislação e impedida de uma autoprogramação. Desta maneira se explica o princípio da ligação da justiça ao direito vigente" (HABERMAS, 1999, v. 1, p. 216). 
formalismo da criação das leis para a sua aplicação pelos juízes, isolandoos da moral, o que, de fato, contraria qualquer senso empírico sobre o que normalmente ocorre, pois assumir uma pretensão de suposta ausência de motivações morais (apenas legais) é, por si só, uma motivação moral. Além disso, este argumento pode, no limite, gerar o paradoxo da legitimidade decorrente da mera legalidade, o que poderia minar a própria concretização do princípio do discurso, pois, se tudo que é legal é legítimo, então a lei pode alterar o seu próprio procedimento, num ato "suicida".

Para compensar as limitações que o princípio democrático sofre a fim de se tornar operante (a delegação para representantes e a regra da maioria em vez do consenso), mediante a passagem de todos para uma maioria de representantes, Habermas sugere dois instrumentos acautelatórios: 1) as decisões da maioria não podem atentar contra $o$ procedimento democrático; e 2) a prevalência dos valores morais sobre as normas jurídicas em matérias que já têm um regramento consensual, pois a ordem legal não pode contrariar princípios morais. ${ }^{43}$

A questão problemática se transformaria, então, em saber se seria possível haver este regramento consensual sobre um padrão moral mínimo. Habermas responde que o fato de existirem interesses opostos dentro da comunidade é levado em conta a partir da consideração de que os princípios podem colidir entre si. $^{44}$ Isso é explicado pela distinção entre discursos de fundamentação e discursos de aplicação. $\mathrm{O}$ fato de uma norma ser geral e abstrata implica reconhecer que há dois momentos: o de sua criação e o de sua aplicação num caso concreto. No primeiro momento, utiliza-se um discurso de fundamentação que busca argumentos que darão validade à norma geral, aplicável "prima facie". No segundo momento, o discurso de aplicação busca, no caso concreto, determinar a adequação daquela norma em confronto com outras normas. Esse segundo discurso tem que se apoiar na quantidade de argumentos normativos

43 DUTRA, 2005, p. 238-240. Para uma análise do mecanismo das cláusulas pétreas como mecanismos de garantia de direitos, princípios e instituições, confira-se: VIEIRA, Oscar Vilhena. A Constituição e sua reserva de Justiça: um ensaio sobre os limites matérias ao poder de reforma. São Paulo: Malheiros, 1999. Nesta obra, o autor não só descreve o fundamento teórico, como também a prática jurídica comparada a partir das experiências das cortes constitucionais brasileira, norte-americana e alemã.

44 HABERMAS, 1999, v. 1, p. 268-269. 
relevantes naquela situação. Num caso concreto, uma norma que diga "as promessas devem ser cumpridas" pode entrar em conflito com uma que diga "as pessoas necessitadas devem ser ajudadas". Embora ambas sejam normas válidas, somente uma será adequada. ${ }^{45}$

Essa solução levanta outro problema: se toda norma válida depende do caso concreto para ser aplicada, então o seu significado mudará constantemente, passando-se a depender da História, que trará as situações imprevisíveis. Ocorre, então, uma problematização da segurança jurídica. Uma primeira resposta seria a de que a própria segurança jurídica seria um princípio a ser colocado em colisão com os demais, deixando aos membros da comunidade uma única certeza: a de que no processo somente serão considerados os argumentos relevantes. ${ }^{46}$ Outra resposta parte da ideia de paradigmas como descrições generalizadas, mais ou menos sistematizadas, fundadas a partir de um saber de orientação cultural. Representam ideologias dos direito, tais como os modelos do Estado liberal burguês ou o Estado socialista. Esses paradigmas aliviam o juiz Hércules de buscar sua decisão no meio de um conjunto desordenado de princípios. Como estes paradigmas tendem a se estabilizar em ideologias fechadas que não dão abertura a novas interpretações, a questão se deslocaria, então, para uma compreensão procedimentalista do direito que permita o diálogo entre paradigmas. ${ }^{47}$

Logo, mesmo Habermas admite a necessidade de fugir do formalismo mediante inclusão de mecanismos ou técnicas políticas que assegurem certos valores representativos de ideologias.

\subsection{A pretensão de veracidade e o processo litigioso}

O segundo "nó" a ser desatado é a pressuposição de que todo discurso contém uma pretensão de veracidade e inteligibilidade. Isto é, trata-se de questionar a ideia de que os falantes desejam chegar a um consenso, que expõem seus argumentos de forma ética e de acordo com as regras do raciocínio. ${ }^{48}$

\footnotetext{
45 HABERMAS, 1999, v. 1, p. 269-272.

46 HABERMAS, 1999, v. 1, p. 272-274.

47 HABERMAS, 1999, v. 1, p. 274-276.

48 Para uma exposição mais detalhada, vide HABERMAS, 1999, v. 1, p. 274-276.
} 
Como bem aponta Dutra, são condições imprescindíveis, segundo a teoria habermasiana, para qualquer entendimento, que: 1) haja o cumprimento das quatro pretensões de validade; 2 ) a resolução discursiva destas pretensões pelo princípio do discurso; e 3) a observância do primado da racionalidade comunicativa sobre a estratégica. Essas são condições inevitáveis que qualquer ação comunicativa deve cumprir como condição necessária de sua possibilidade. ${ }^{49}$

Isso não ocorre na prática jurídica, que, por definição, envolve uma disputa sobre um determinado bem. Há não só a tentativa, pelos falantes, de uso estratégico dos seus argumentos, como também a possibilidade de não cumprir as condições de validade no intuito de obter vantagem sobre o adversário. É bem verdade que existem mecanismos jurídicos elaborados para tentar reduzir essa circunstância, tais como os deveres processuais de boa-fé e lealdade, a tipificação de crimes de falsidade ou fraude etc. Todavia, em vez de negarem a existência do "nó", estes mecanismos a confirmam.

Esta objeção corresponde à quinta negativa cética, ${ }^{50}$ qual seja, "negação ou recusa ao jogo da argumentação". Habermas a rebate com o argumento de que o cético não pode negar que vive num mundo em que compartilha uma forma de vida sociocultural. Logo, o cético está imerso num processo de socialização que lhe transmite culturalmente estruturas comunicativas e uma esfera de eticidade. Ele não tem como saltar fora do agir comunicativo, sob pena de, agindo apenas estrategicamente, tornarse esquizofrênico ou suicida. ${ }^{51}$

Esta resposta, porém, não afasta a objeção (total ou parcial) à ação comunicativa no plano do Direito (salvo se esta for compreendida como uma situação ideal), porquanto o jogo da argumentação, no caso, é orientado não para a finalidade de um entendimento consensual, mas sim para uma vitória num conflito.

Logo, qualquer que seja a teoria por detrás da prática jurídica, ela tem que partir do pressuposto de que não há a pretensão à veracidade, senão a pretensão à aparência de veracidade como forma retórica de alcançar a pretensão ao êxito inerente a uma ação estratégica.

49 DUTRA, 2005, p. 57.

50 DUTRA, 2005, p. 57.

51 DUTRA, 2005, p. 179-180. 


\subsection{0 acordo final}

O terceiro ponto a ser considerado é que a teoria consensual da verdade pressupõe, ao menos no modelo ideal, que as partes chegarão, em algum momento, a algum tipo de acordo, ainda que provisório e sujeito à alteração futura. Desconsidera, assim, a necessidade e a existência de um terceiro sujeito que, em determinadas situações, impõe sua vontade aos falantes, se e quando estes não alcançarem o acordo. O mundo da vida demonstra que essa conciliação não é a regra, mas sim a exceção, e, naqueles casos, há a necessidade de intervenção de um terceiro, que, na prática ocidental moderna é primordialmente papel do Estado.

Há um corte no procedimento de argumentação, que não terminará no consenso mútuo, mas sim na imposição de uma solução por um terceiro. Logo, a argumentação jurídica impõe um limite ao discurso, impossibilitando chegar-se ao discurso ideal.

\subsection{O corte epistemológico}

O quarto "nó", tão ou mais importante quanto os anteriores, é o radical corte epistemológico produzido pela distinção entre contexto de descoberta e contexto de justificativa. Ao buscar uma autonomia entre direito, política e moral, o neoconstitucionalismo assume, como princípio explícito de sua fundação, a desconsideração dos fatores políticos, psíquicos e éticos que levam o juiz a tomar determinadas decisões. Em outras palavras, o objeto de estudo é a justificação apresentada na decisão, e não os motivos que levaram a tomá-la. A concentração de esforços no estudo de como as decisões são apresentadas desconsidera os reais motivos que lhe deram origem e determinaram seu conteúdo.

Se a finalidade da teoria jurídica for descritiva, ela não pode prescindir de apontar os motivos que levaram à decisão, já que sua descrição será superficial e restrita àquilo que o sujeito decidir apontar como relevante, tornando a teoria totalmente subordinada e dependente do sujeito julgador. Se a finalidade for prescritiva, ela também não pode desconsiderar as razões que, ao julgamento, sob pena de muito pouco poder sugerir ou determinar como alternativa de solução. Se ela for crítica, então, muito mais necessária se faz a explicitação das condições escondidas, sob pena de se tornar inútil por apontar falhas naquilo que é aparente e não naquilo que é determinante. Ao ser descritiva, a ciência jurídica adota, implicitamente, uma conduta 
prescritiva de ignorar aspectos fundamentais, pois equivale a tacitamente ocultar os demais fatores.

$\mathrm{O}$ argumento da dificuldade de explicitação das motivações ocultas não é suficiente para impedir a tentativa de revelá-las. Com efeito, se assim fosse, não seria possível, por exemplo, investigar, numa demanda criminal, se a ação foi dolosa ou culposa, se estavam presentes os demais elementos subjetivos ${ }^{52}$ ou em diversas situações da vida civil. ${ }^{53}$

\subsection{A alienação no senso comum teórico dos juristas}

O quinto "nó" fundamental do modelo neoconstitucionalista é produzir uma alienação ${ }^{54}$ dos teóricos no sentido de que eles passam a acreditar que a Constituição e as leis são objetos que têm existência objetiva que se fecha nela mesma. ${ }^{55}$ Ao contrário, porém, é necessário atentar-se ao fato de que 'ao negar a 'reificação' do direito, não estou afirmando que ele não seja nada. É uma prática facilmente reconhecível na maior parte de suas manifestações. Contudo, uma prática ou atividade é diferente de um conjunto de conceitos". ${ }^{56}$

52 Por exemplo, a exclusão de criminalidade nos crimes contra a honra quando presente o "animus jocandi", o especial fim de transmitir a outrem moléstia grave de que está contaminado no crime de Perigo de contágio de moléstia grave (art. 131, do Código Penal), a intenção de lucro como condição da imposição da pena de multa no crime de favorecimento da prostituição (art. 228, §3ำ, do Código Penal), a finalidade de cometer crimes no crime de quadrilha ou bando (art. 288, do Código Penal) etc.

53 Como exemplo: o desvio de finalidade como hipótese de desconsideração da personalidade jurídica (art. 50, do Código Civil), a intenção manifesta de mudar o domicílio como condição para a transferência deste pela alteração de residência (art. 74, do Código Civil), a intenção de não prejudicar outrem como condição para o exercício do direito de propriedade (art. 1228, §2º , do Código Civil) etc.

54 Por alienação, a partir dos estudos de Feuerbach sobre religião, entende-se "o fenômeno pelo qual os homens criam ou produzem alguma coisa, dão independência a essa criatura como se ela existisse por si mesma e em si mesma, deixam-se governar por ela como se ela tivesse poder em si e por si mesma, não se reconhecem na obra que criaram, fazendo-a um ser-outro, separado dos homens, superior a eles e com poder sobre eles" (CHAUÍ, 1997, p. 170).

55 Vide, como consequência deste tipo de pensamento, a descrição histórico-jurídica da ascensão do nazismo na alemanha entre-guerras. Para o tema: VIEIRA, 1999, p. 100-106.

56 POSNER, Richard. Problemas de filosofia do direito. Tradução de Jefferson Luiz Camargo. Revisão Técnica Mariana Mota Prado. São Paulo: Martins Fontes, 2007, p. 303. 
Ao descrever a origem marxista da ideia de alienação social, Chaú descreve que a evolução da práxis (ação sociopolítica e histórica) pode ser explicada pelo estudo das alterações das condições materiais (conjunto de práticas, organizações e estruturas nascidas da divisão social do trabalho para garantir a sobrevivência do homem pelo trabalho e troca dos produtos do trabalho). A variação dessas condições materiais constitui a histórica da sociedade, indicando os seus modos de produção. A alienação social é o desconhecimento pelo homem do fato de que suas ações instituíram a Sociedade e de que ele é capaz de mudar a forma pela qual esta Sociedade influi nos seus pensamentos e ações. ${ }^{57}$ A alienação se daria, então, sob três grandes formas: 1) alienação social, na qual os humanos não se reconhecem como produtores das instituições sociopolíticas e aceitam passivamente aquilo que elas lhe dirigem ou reagem apenas individualmente; 2) alienação econômica, na qual os produtores não se reconhecem com produtores dos objetos decorrentes do seu trabalho, ignorando que foi o trabalho de sua classe social que produziu as mercadorias, fábricas e outros bens; 3) alienação intelectual, em que a divisão entre trabalho intelectual e trabalho material produz a crença dos intelectuais de que as ideias são produzidas por eles, passando a acreditar que elas estão na realidade e, com isso, eles deixam-se dominar por elas. ${ }^{58}$

Assim, muito embora exista um papel com diversas palavras inscritas nele, o meio físico em que é disponibilizado o texto não representa a ideia de Constituição. Não se trata, aqui, de renovar a ideia de que ela é uma folha de papel que depende apenas e exclusivamente dos fatores reais de poder, ${ }^{59}$ mas sim compreender que o seu conteúdo não

57 CHAUÍ, 1997, p. 170-172.

58 CHAUÍ, 1997, p. 172-173.

59 O conceito sociológico vem de Lassale, para quem a Constituição era o acerto entre os grupos no poder, o rei/exército, a aristocracia, os industriais e banqueiros, o alto clero, os líderes políticos e a burguesia, ou seja, os fatores reais de poder estabelecem a constituição real. Segundo ele, um conceito de Constituição fundado na simples ideia de que ela seria um pacto ou uma lei fundamental não explica a sua essência, mas apenas descreve o que ela faz. Por isso, ele expande seu raciocínio, afirmando que, por se tratar de uma lei fundamental da nação, a Constituição implica a noção de uma força eficaz e determinante que atue sobre tudo que nela se baseia, ou seja, os fatores reais de poder que atuam no seio de cada sociedade e determinam que a sua organização política não possa ser outra que não a existente como tal. Essa organização substancial é a Constituição real, 
foi fruto de um ou vários seres iluminados que a inscreveram em pedra, tal qual Deus teria feito com os dez mandamentos. Como qualquer outra lei da história da civilização, a Constituição, foi, sim, um acordo possível entre congressistas. ${ }^{60}$

que pode, ou não, ser igual à Constituição escrita. Isso explicita a compreensão de que os problemas constitucionais não são problemas de direito, mas de poder. Para Lassale, a verdadeira Constituição somente tem por base os fatores reais e efetivos do poder e as constituições escritas não têm valor nem são duráveis a não ser que exprimam fielmente aquela realidade social (LASSALE, Ferdinand. A essência da Constituição. 5. ed. Rio de Janeiro: Lúmen Júris, 2002, p. 5, 11, 27, 33, 40).

${ }^{60}$ Para o tema, como breve notícia, vide: "Coorporações dominaram as votações [...] O ex-deputado Nélson Jobim, um dos mais atuantes personagens do processo constituinte - foi uma espécie de braço direito de Ulysses Guimarães, presidente da Assembléia -, diz que, para entender limitações e defeitos da Constituição, é preciso rever sua gênese e o momento histórico de sua concepção. O País saía de duas décadas de autoritarismo e havia reivindicações múltiplas represadas na sociedade. O problema, diz ele [...] é que as reivindicações da sociedade foram confundidas com as das corporações. [...]. Jobim acrescenta: 'A grande disputa na Comissão de Sistematização era para empurrar o que as corporações queriam aprovar. Achava-se que atender àquelas pressões era algo altamente democrático. Só depois é que se deu conta de que representavam interesses segmentados'. [...]. Outra deficiência, apontada por Jobim - hoje ministro do Supremo Tribunal Federal -, relacionada ao contexto político da época, refere-se à pobreza temática dos constituintes. As forças políticas que haviam triunfado sobre o regime militar-comunistas, estatizantes, sociais-democratas, socialistas, trabalhistas, liberais - temiam discutir temas específicos, como economia, formato político do Estado ou o que pudesse provocar divisão ideológica. O discurso que os unia era o do ideal democrático. Jobim recapitula: 'Quando se foi votar a Ordem Econômica, qual era o material crítico que tínhamos? Era o que estava guardado na gaveta desde a década de 50: nacionalismo, intervencionismo etc. Durante todo o período da ditadura, ninguém discutiu o modelo econômico. Não houve má-fé. Achava-se que era isso mesmo. Tudo o que se votou em relação a nacionalismo, intervencionismo, estatização do subsolo correspondia a essa visão anacrônica'. Em tal circunstância, inevitável que houvesse despreparo técnico. É ainda Jobim quem recorda: 'Todos sabiam tudo sobre direitos humanos, direitos e garantias individuais. Tanto que essa parte da Constituição é irretocável. Mas sobre economia, relação Estado-economia, o desenho que se tinha era antigo. O tema serviço público foi abocanhado pelas corporações. Não havia ninguém para defender o Estado. Apenas no final, quando se votou o texto sobre os tributos, quem tentou salvar alguma coisa foi o ministro da Fazenda, Maílson da Nóbrega. Ele percebeu que aquela forma de financiar a União ia quebrar tudo'. [...] Articulavam-se maiorias de duas maneiras: uma, quando a matéria era pacífica; outra, por meio de acordo para não votar a questão e remetê-la à regulamentação em lei ordinária ou complementar. Ou seja, adiava-se o conflito'. Mesmo aí, não havia critério: ia para a lei ordinária o que era menos polêmico e para a lei complementar o que deveria ter mais peso. Isso, segundo Jobim, explica por que a Constituição tem tantos dispositivos que dependem de 
Um exemplo prático disso é tomado do voto do Ministro Nelson Jobim, que participou do processo constituinte, no qual ele afirma, textualmente, que:

\begin{abstract}
A Constituição, quando remete matérias, ora para a legislação ordinária, ora para a legislação complementar, não leva em consideração, no mais das vezes, a natureza da matéria. A opção para remessa à legislação ordinária decorre de uma questão política, quando da discussão do texto. Não havendo entendimento para um texto acordado, resta a disputa pelo voto. No entanto, pode ocorrer - e na Constituinte de 1987/8 ocorreu várias vezes - que as correntes em debate não contem com a maioria necessária para a aprovação de suas teses. Desta forma, acordam as correntes, em relação à questão que inviabiliza um entendimento de conteúdo, que a matéria seja remetida para legislação infraconstitucional. Chamávamos a esse entendimento de "compromisso dilatório". ${ }^{61}$
\end{abstract}

Isso não significa que não exista um valor da Constituição ou que ela não tenha algum tipo de existência; significa, sim, que ela é, simultaneamente, o seu valor e sua prática. Quando alguém discute se a norma " $X$ " ofende a Constituição, ele discute se a norma " $X$ " ofende aquilo que ele acha que é a Constituição, seja por entendê-la como o texto literal aprovado, seja por compreendê-la como o conjunto de sentidos atribuídos pelas decisões da Corte Constitucional. Ela não é nem uma tábua com dizeres inscritos a partir de uma sabedoria revelada e nem tampouco uma simples folha de papel ou um contrato hipotético firmado, e sim uma das principais diretrizes de resolução de conflitos de interesse, cuja observância se dá proporcionalmente à importância moral e política que lhe é atribuída.

Além disso, a postergação do conflito (ou a sua não solução) durante a elaboração da Constituição ou das leis implica transferir o embate

regulamentação. Outro recurso para aprovar textos polêmicos era torná-los ambíguos. Discutiu-se, por exemplo, se o repouso semanal remunerado devia ser obrigatoriamente aos domingos. Diante do impasse, recorda Jobim, o relator Bernardo Cabral optou pelo recurso ao advérbio de modo: 'Repouso semanal remunerado preferencialmente aos domingos'. [...].” (FABIANO, Ruy; SAMARCO, Christiane; BASILE, Juliano. Gazeta Mercantil S/A., G M, p. A10. Disponível em: <http://www.senado.gov.br/sf/noticia/ senamidia/historico/1998/9/zn093011.htm>.

61 Voto proferido no curso da Medida Cautelar n 1.480, julgado em 04/09/1997. Para maiores detalhes sobre o processo constituinte de 1988, vide: VIEIRA, 1999, p. 125-134. 
político para o plano judicial, fazendo o Direito confundir-se, cada vez mais, com a política e a moral.

\subsection{A ausência de metacritérios e o uso retórico dos processos interpretativos}

Outro nó que aperta o neoconstitucionalismo é a ausência de metacritérios ou postulados que assegurem a suposta melhor interpretação ou a mais correta possível. Em verdade, essa ausência não é nova, pois apenas reproduz, no discurso dos princípios, os problemas do discurso sobre métodos de interpretação.

A ampliação da atuação jurisdicional pode deslocar o uso funcional dos métodos de interpretação para os princípios jurídicos. Streck, utilizando argumentos do Warat, afirma que a doutrina dos métodos ou técnicas interpretativas oculta o seu compromisso ideológico. Esses métodos servem como instâncias retóricas com função de canalizar, mediante aparente neutralidade, valores escolhidos para se preservar. Isso porque, existindo uma fungibilidade no uso das técnicas pela ausência de metarregras hierarquizadoras do seu uso, eles acabam funcionando como reservas de recursos de argumentação e o seu uso acaba sendo arbitrário. ${ }^{62}$

${ }^{62}$ STRECK, 2004, p. 113-114. Jocosamente, é possível comparar esta ausência de metarregras com a piada da "Catchanga": Num cassino da fronteira, chega um fazendeiro rico que olha cada uma das mesas e se senta sozinho num canto do salão. Querendo tirar um pouco do dinheiro, o dono do cassino fica curioso e pergunta: - O Senhor não vai jogar nada ? - "No me gusta lo poker ni lo black jack. Solo juego la Catchanga", respondeu o ricaço. O dono do cassino não conhecia este jogo. Ele volta ao salão e pergunta aos crupiês se algum deles conhecia a tal da Catchanga. Como ninguém conhecia aquele jogo, o dono do cassino teve uma ideia: chamou os seus melhores crupiês e lhes disse: "vocês dão as cartas para o pato e deixam ele jogando. No início, vamos perder um pouco de dinheiro, mas com o tempo vocês sacam as regras e no final nós o depenamos". Os jogadores convidaram o cliente e sentaram-se na mesa. Na primeira rodada, o ricaço pegou o maço, distribuiu três cartas para cada um. Todos ficaram parados olhando as cartas. O ricaço, subitamente, grita "Catchanga!" e pega todas as fichas da mesa. Na segunda rodada o mesmo aconteceu. Idem na terceira e na quarta. Isso já ia durante a noite inteira. O cassino já estava quase falindo e os crupiês não estavam entendendo nada. De repente, um dos jogadores pensou: "este cara está nos enganando" e, ao receber as suas cartas, antes que o ricaço pudesse fazer algo, gritou: "Catchanga!". Quando o jogador ia pegar as fichas, o ricaço baixou as suas cartas, disse: "No, no. Catchanga Real!" e levou o dinheiro... Ou seja: o uso retórico de argumentos guardados na "manga" impede a solução racional da argumentação, gerando uma discricionariedade disfarçada de racionalidade. 


\subsection{A subjetividade escondida na técnica da ponderação}

Adentrando na dogmática do neoconstitucionalismo, o sétimo aspecto relevante é que esta doutrina aponta, em geral, a observância do princípio da proporcionalidade como instrumento para sanar a ausência de uma espécie de metarregra hermenêutica. No discurso, há a pretensão implícita de que esta regra proporcione uma objetividade na decisão judicial que a legitimaria. Isso, contudo, não observa que a aparente e pretendida objetividade do postulado da proporcionalidade esconde a subjetividade existente no sopesamento de valores implícito no subprincípio da proporcionalidade em sentido estrito.

Porém, este mecanismo é insuficiente e perigoso para tal fim por dois motivos: 1) é que a assunção de um princípio da proporcionalidade revela uma circularidade na proposta teórica, ou seja, busca evitar o idealismo ${ }^{63}$ dos princípios mediante uso de um recurso do próprio sistema idealista (outro princípio). 2) consiste na falha intrínseca deste mecanismo, qual seja, o de mascarar o viés subjetivo existente na chamada terceira etapa, em que o julgador escolheria a solução "menos custosa".

Com relação ao primeiro motivo, ao uso do princípio da proporcionalidade, a questão é desdobramento do perigo de se ater a modelos abstratos e especulativos que não guardam ligação com a prática do mundo da vida. Essa ligação é necessária porque, se a finalidade do direito é regular a conduta humana, então esta conduta real e concreta tem que estar presente de alguma forma no interior da teoria, sob pena de ruptura entre os sistemas. Com efeito, no plano histórico da filosofia,

${ }^{63}$ Corrente filosófica que concebe o direito como pertencente ao mundo das ideias, sendo a validade da norma captada imediatamente pela razão, independente dos fenômenos sensíveis. Dividem-se entre: 1) idealistas axiológicos, para quem a ideia de justiça é constituinte e fundamental do direito; e 2) idealistas formais, como Kelsen, para quem as questões éticas e políticas estão separadas do direito (ALVES, Alaôr Caffé. Apresentação. In: ROSS, Alf. Direito e justiça. Bauru: EDIPRO, 2003, p. 11). O idealismo difere a moral do direito pois este é um fato determinado histórica e geograficamente, sendo fenômeno e validade ao mesmo tempo; aquela, a moral, origina-se da razão, sendo pura validade. Por isso a divisão entre: 1) idealismo material, que entende a Justiça como princípio fundamental do direito, limitando a sua validade ao dizer que a norma injusta é mera violência; e 2) idealismo formal, que afasta a censura ética e entende como direito qualquer ordem vigente no mundo dos fatos, pois o seu conhecimento não visa à descrição de algo fático, mas sim à apreensão do que é válido (ROSS, Alf. Direito e justiça. Tradução de Edson Bini. Bauru: EDIPRO, 2003, p. 91-92). 
duas situações apontam a necessidade de uma volta ao empirismo ou pragmatismo: a) a questão da salvação do modelo ou da experiência e b) a concepção de lógica de Toulmin.

Quanto à primeira situação, um momento importante da metodologia científica ocorreu com a inversão das prioridades entre salvar um modelo ou salvar os fenômenos. Exemplificando: São Tomás de Aquino defendeu o sistema cosmológico elaborado por Aristóteles contra os astrônomos de Alexandria dizendo que, enquanto esses baseavam suas hipóteses em observações e cálculos, Aristóteles deduzia a sua teoria a partir de princípios primeiros, sendo, por isso, verdadeira. Assim, a ciência moderna surge quando se percebe a importância de salvar fenômenos quando a experimentação demonstra que a teoria existente não responde adequadamente, superando-se, assim, a metafísica especulativa ${ }^{64}$ Logo, se a teoria não sobrevive à verificação empírica, a sua hipótese é posta em dúvida, e devem ser aprimorados os modelos explicativos.

Em relação à concepção lógica de Toulmin, embora a obra de Toulmin seja mais conhecida em razão da estruturação gráfica que ele apresenta para distinguir os tipos de argumentos, ela aponta a falha no ideal de um sistema lógico de verdades eternas expressa em termos matemáticos, o que, na Idade Média, acabou levando à substituição da lógica por afirmações pela lógica proposicional. Segundo ele, não é possível colocar os argumentos em modelos matemáticos intemporais sem que isso desfigure a aceitabilidade daqueles e sem que isso anule a função da lógica de discutir a validade de julgamentos de valor sobre outros conhecimentos que não sejam exclusivamente matemáticos. Para demonstrar isso, Toulmin transforma tabelas de competições esportivas numa "álgebra" formal que aponta as chances de cruzamentos entre os competidores; a partir dela, aponta que as limitações nas operações de cálculo decorrem da natureza intrínseca do problema original. Isto é, ele demonstra que nos cálculos "feitos sob medida" é difícil separar as impossibilidades e necessidades puramente formais das características empíricas a que estão associadas. Segundo ele, os lógicos esquecem que é necessário criar uma conexão entre o cálculo e sua aplicação, pois interpretam as propriedades puramente formais como se elas possuíssem

${ }^{64}$ MARCONDES, Danilo. Iniciação à história da filosofia. 9. ed. Rio de Janeiro: Jorge Zahar Ed., 2005b, p. 150-152. 
uma força por elas mesmas; não percebem, porém, que essa força de convencimento só existe a partir da ligação com o problema concreto. Por isso, as necessidades e possibilidades formais dependem das necessidades e possibilidades da vida prática e só podem ser aplicadas para expressar verdades decorrentes de conceitos práticos. ${ }^{65}$

Quanto ao segundo item 2), a narração usual da doutrina sobre o procedimento de aplicação do princípio da proporcionalidade incorre no equívoco de declarar o terceiro passo como objetivo ou em tentar reduzir o papel da subjetividade do julgador. Porém, dizer que o manifestante em greve de forme deve ser alimentado após cair inconsciente é dizer que o bem vida tem mais valor do que a vontade daquele. Não se quer, por óbvio, dizer que ela tem, ou não, mais valor, mas sim afirmar que isso, em última instância, é admitir que o juiz ou intérprete decidirá conforme determinados valores. Ao dizer, como fez o Supremo Tribunal Federal, que liberdade de expressão não sobrepuja o direito à não discriminação racial, há, claramente, uma escolha feita a partir de valores. Por isso, ao escolher, no caso concreto, o bem "A" em detrimento do "B", o juiz está avaliando este como menos valioso do que aquele. ${ }^{66}$

Assim, sob o ideal de uma suposta objetividade, esconde-se a subjetividade inerente da qual o ser humano (incluindo os juízes) não pode escapar; quando, ao contrário, ela deve ser explicitada claramente, evitando-se o corte epistemológico.

${ }_{65}$ TOULMIN, TOULMIN, Stephen Edelston. Os usos do argumento. Tradução de Reinaldo Guarany. 2. ed. São Paulo: Martins Fontes, 2006, p. 252-294. Assim, por exemplo, numa decisão acerca do direito à saúde, não basta indicar, formalmente, que todos têm direito ao melhor tipo de medicamento ou apenas ao mais adequado; é necessário apontar, no caso concreto, todos os dados empíricos possíveis (tais como custo individual, o percentual do orçamento destinado ao tema, as estatísticas de previsão de melhora etc.).

${ }_{66}$ A discussão sobre os valores exige mais espaço do que seria possível neste trabalho, valendo consignar, porém, que há diversas correntes sobre o tema, desde quem defenda que o valor é algo inerente às coisas e às ações (teorias cognitivistas) até que ele é um estado de espírito subjetivo que reflete escolhas voluntárias (teorias não cognitivistas). Cada uma dessas teorias abriga diversas compreensões distintas. Para tema: BOLLMANN, Vilian. Princípios de Seguridade Social: o direito previdenciário no Brasil sob o enfoque da Teoria da Justiça de Aristóteles. 2007. 133p. Dissertação (Mestrado em Ciência Jurídica) - Universidade do Vale do Itajaí, Itajaí, 2007, p. 78-87. 


\subsection{A omissão da distinção com as políticas ou diretrizes}

O oitavo "nó" refere-se a uma espécie de importação parcial do conjunto teórico embutido na compreensão de Dworkin sobre os princípios. A prática jurídica neoconstitucionalista confunde diretrizes e princípios, aplicando aqueles como se estes fossem.

É comum, por exemplo, encontrar julgados que tratam de ponderação entre segurança pública e liberdade do indivíduo ou entre salvaguarda da economia e direito de comércio pelo importador, como se ambos fossem mandamentos decorrentes de princípios.

Ocorre que o conceito de princípio usado por Dworkin é muito mais limitado do que o do senso comum teórico dos constitucionalistas brasileiros, pois não engloba bens coletivos. ${ }^{67}$ Em verdade, a teoria dos princípios de Dworkin decorre de uma Teoria da aplicação do direito e esta decorre de uma Teoria do Direito que está ligada a uma específica Teoria da (obrigação) Política.

Ao tratar dos direitos concorrentes, Dworkin defende que um direito individual (direito moral contra a maioria) só pode ser desafiado por outro direito individual, e não por um direito da maioria. Ou seja, um direito contra o governo deve ser um direito ainda que seja contrário à vontade da maioria e outro indivíduo só tem um direito concorrente digno de proteção se este puder, enquanto indivíduo, exigir que o governo o proteja pelo fato de deter esta qualidade. ${ }^{68}$

Isso não significa que os tribunais não possam decidir com base em argumentos de política; ao contrário, Dworkin admite que isso acontece e que possa acontecer; porém, ele pondera que deve haver maior discussão política, jurídica, moral e teórica sobre as decisões judiciais que geram regras de direito prospectivas (ativismo judicial ${ }^{69}$ ) e, por consequência,

${ }^{67}$ Confira-se, por exemplo: DWORKIN, 2002, p. 128-133. Nesta passagem, para afastar o óbice do governo dos juízes, ele diz claramente que questões de política devem ser decididas em procedimentos amplos.

68 DWORKIN, Ronald. Levando os Direitos a sério, p. 292-299. Para uma discussão mais profunda sobre a distinção entre argumentos de princípio e argumentos de política, vide DWORKIN, 2002, p. 451-474.

69 Para Dworkin, o ativismo judicial é a filosofia de interpretação jurídica pela qual os tribunais devem aceitar a orientação dada pelas cláusulas gerais constitucionais, tais como igualdade, liberdade, devido processo legal, devendo desenvolver conceitos para elas e 
aumento de postura administrativa pelos tribunais ${ }^{70}$ com uma possível invasão da esfera de atuação dos poderes Executivo e Legislativo, especialmente quanto à criação de políticas públicas. ${ }^{71}$

\subsection{O uso de expressões retóricas}

O quinto "nó" do neoconstitucionalismo brasileiro contemporâneo é a desconsideração crítica do excessivo uso de expressões vagas como "dignidade da pessoa humana", "princípio republicano", "democracia" etc.

Um exemplo dado pela doutrina mais crítica refere-se aos julgamentos do STF que recorrem à proporcionalidade como sinônimo de razoabilidade apenas com a função de argumento retórico e não

revê-los periodicamente, para usá-los no controle de atos do Legislativo e do Executivo. Segundo ele, a teoria política adotada pelo constitucionalismo norte-americano requer o ativismo judicial, porquanto a necessidade de direitos contra a maioria implica direitos morais contra o Estado, que só podem ser assegurados pelo Judiciário. Isso, porém, deve ser feito atentando-se à possibilidade de que os juízes venham fazer más escolhas, seja por excesso, seja por omissão; mas não se deve exagerar neste medo, e sim observar, sempre, a necessidade de incluir a filosofia moral (tal como a de Rawls) nas discussões jurídicas (DWORKIN, 2002, p. 215, 231-234).

70 DWORKIN, 2002, p. 520-529.

71 Como bem apontado pelo Juiz Federal Emmerson Gazda, "Nesse cenário é certo que a definição de políticas públicas e regulamentação de leis é atividade típica do Executivo. Já a elaboração de leis é função típica do Legislativo. Vê-se, portanto, no que se refere ao direito à saúde, que o Legislativo tem uma função regulamentar de certa importância, e o Executivo, tanto na esfera federal, quanto estadual e municipal, tem um papel principal de grande responsabilidade, sendo seu o poder de definir, em grande medida, o presente e o futuro da saúde pública no Brasil. Quanto ao Judiciário, por sua vez, tem-se que sua atividade em definir políticas públicas e atuar como legislador positivo é bastante reduzida. Assim é que o Juiz não pode, por exemplo, mandar o Executivo Federal ou Estadual duplicar uma rodovia que causa inúmeras mortes (como seria de se fazer com a BR-280 ou BR-470). Também não pode o Juiz determinar que seja fixado um saláriomínimo efetivamente capaz de atender ao trabalhador em "suas necessidades vitais básicas e às de sua família, com moradia, alimentação, educação, saúde, lazer, vestuário, higiene, transporte e previdência social [...]", conforme prevê artigo 7o, IV, da CF/88. Nessas situações, onde se inclui a saúde, prepondera a definição e execução de política pública, o que é atividade sujeita a restrições quanto ao controle judicial" (sentença proferida nos autos de $n^{\mathrm{o}}$ 2008.72.59.000678-7). Para o tema, apontando limitações ao controle jurisdicional de políticas públicas possíveis a partir do texto constitucional, confira-se: BOLLMANN, Vilian. Políticas públicas, direitos fundamentais e os limites da atuação do Poder Judiciário. In: VAZ, Paulo Afonso BRUM; SCHÄFER, Jairo Gilberto (Org.). Curso modular de direito constitucional. Florianópolis: Conceito Editorial, 2008. 
sistemático, gerando decisões que, para afastar alguma conduta considerada supostamente abusiva, recorre à fórmula "à luz do princípio da proporcionalidade ou da razoabilidade, o ato deve ser considerado inconstitucional". ${ }^{72}$ Como exemplo, Silva cita o HC 76.060-4, no qual se discutia a coleta de sangue do pai para exame de paternidade, em que, apesar de salientada a importância da proporcionalidade, ela não é aplicada de forma estruturada, mas somente citada. ${ }^{73}$

O uso de termos ambíguos que provocam uma adesão é uma falácia não formal consistente no uso de um enunciado cujo significado não é claro, mas que sugere um resultado geralmente aceito. Um exemplo é o uso de expressões como "democracia", que tornam a pessoa propensa a aceitá-la, ainda que não haja um acordo semântico claro sobre o conceito de democracia que usam. ${ }^{74}$

É bem verdade que tal situação não é intrínseca do modelo do neoconstitucionalismo, mas sim uma conjuntura das práticas jurídicas brasileiras. Porém, o fundamental é que a assunção da normatividade dos princípios, usualmente construídos a partir de expressões ambíguas com carga emotiva positiva, maximiza o uso deste tipo de instrumento como justificador de decisões que, analisadas mais criteriosamente, podem se revelar arbitrárias. Esta consequência, ainda que não querida pela doutrina, obriga a estruturação do modelo a partir de uma perspectiva que permita descortinar o uso retórico dos princípios.

\section{Uma proposta de desate}

A crítica, então, chega ao seu momento crucial: saber se dela pode surgir algo novo.

Conforme vislumbrado acima, não se trata de apontar uma resposta mágica e definitiva, mas sim a sugestão de caminhos ou alternativas ao discurso de repetir mais das mesmas soluções.

72 SILVA, Luís Virgílio Afonso da. O proporcional e o razoável. Revista dos Tribunais, ano 91, v. 798, abr. 2002, p. 31.

73 SILVA, 2002, p. 31. Segundo ele: "Não é feita nenhuma referência a algum processo racional e estruturado de controle da proporcionalidade do ato questionado, nem mesmo um real cotejo entre os fins almejados e utilizados. O raciocínio aplicado costuma ser muito mais simplista e mecânico".

74 WARAT, Luiz Alberto. Introdução geral ao direito, p. 158-159. 
Para isso, a construção de uma proposta jurídica emancipatória que minimize as contradições apontadas deve passar pela explicitação de pressupostos aceitos (ainda que provisoriamente).

\subsection{A rejeição da hipótese cínica}

O primeiro aspecto aceito é a possibilidade de rejeição inicial da hipótese cínica que funda as propostas céticas. A hipótese cínica é um modo de compreensão das relações sociais de poder que pode ser resumida no seguinte lema:

O poder basta em si mesmo. O Estado não é diferente de um bando de ladrões. As idéias de legitimidade do poder e da necessidade de submetê-lo a limites são tentativas ideológicas de mascarar a descrição da realidade. O discurso da Ética não leva a nenhum resultado útil por tentar amarrar a conduta humana a freios que não são naturais e que dependem da vontade de obedecer. Esta vontade de obedecer é uma mera vontade e, como tal, pode mudar. Por isso, não cabe à Ciência ou à Filosofia dizer como a conduta do governante deveria ser, mas sim dizer como ela realmente é. Disso decorre que a Constituição é somente uma folha de papel. Se as relações de poder de fato decidirem destruí-la ou ignorá-la, o farão, expressa ou sub-repticiamente.

A resposta a esta hipótese cínica é a formulada a partir do estudo sobre a legitimidade do poder e do Estado, que passa pelo reconhecimento pragmático de que a força, por si só, não consegue, a longo prazo, estabelecer e manter uma estrutura de poder fundada unicamente sobre aquele meio de pressão. O estabelecimento do Estado implica uma estratégia de manutenção dessa estrutura e, simultaneamente, de controle deste e por meio deste. Por isso, existe, por detrás de qualquer poder, uma condição de valores consensualmente aceitos que refletem os interesses, aspirações e necessidades de uma comunidade com a qual o poder tem que se adequar. A política é compreendida como a única resolução prática da antinomia entre a força e a liberdade, por meio da justiça. A justiça passa a ser um conceito de legitimação do poder de coação. Justificada a existência do Estado pela necessidade de superação do Estado de natureza, a Justiça política tem que definir estratégias para que os detentores do poder não abusem deste. Uma delas é a positivação de uma Democracia 
com respeito a direitos fundamentais, evitando-se a tirania da maioria; outra, a desobediência civil. Além delas, a institucionalização de um Estado social também é uma estratégia de Justiça política para assegurar condições econômicas e sociais mínimas que permitam o desenvolvimento do modelo de cooperação.

A partir da questão da legitimidade, a relação entre direito e política se inverte: não é mais o poder político que produz o direito, mas o direito que justifica o poder político. No início de uma comunidade política, o poder que institui um grupo é sempre um poder de fato; porém, eventos temporários darão vida a um sistema duradouro se o respectivo poder for institucionalizado pelo direito. A noção de legitimidade busca dar uma justificação do poder político, para diferenciá-lo de um simples poder de fato. A referência a um princípio de legitimação - como o do justo título opera diversas transformações: 1) o poder de impor deveres passa a ser um direito de exigir condutas; 2) a obediência dos destinatários muda para um dever de agir conforme a norma; e 3) a relação de força vira uma relação jurídica. A obrigação política de respeito às normas não se dá pelo uso exclusivo da força física, mas sim pelo sentimento de se estar cumprindo obrigações genuínas. Se o direito existe, ele deve prover uma justificativa para o uso do poder. Logo, qualquer teoria política do direito deve não só incluir o fundamento das proposições jurídicas individualizadas, mas também o fundamento da força do direito, isto é, do motivo pelo qual o direito pode coagir. Sem essa justificação, as divergências entre os membros de uma comunidade levariam não só à desobediência civil, mas também à própria desestruturação da sociedade.

Diante de tudo isso, é possível vislumbrar que a ausência do sentimento de legitimidade do Estado e de suas normas pelos cidadãos implicaria o enfraquecimento da obrigação política e, no limite, a desobediência civil, rejeitando-se, assim, a hipótese cínica. ${ }^{75}$

\footnotetext{
75 Para a análise mais detalhada desta argumentação: BOLLMANN, 2007, p. 87-95. Para consulta às fontes diretas, confira-se: BOBBIO, Norberto. Teoria geral da política, p. 233-236; DWORKIN, Ronald. O império do direito. São Paulo: Martins Fontes, 1999, p. 134-139, 231-233, 237-244, 251-255; FARAGO, France. A Justiça, p. 161; FARIA, José Eduardo. Poder e legitimidade, p. 22-23; HÖFFE, Otfried. Justiça política, p. 2526/367-381; VIEIRA, 1999, p. 21-23, 203-212, 224-227; WOLKMER, Antônio Carlos. Ideologia, Estado e Direito. 4. ed. São Paulo: Revista dos Tribunais, 2003, p. 80.
} 
Essa rejeição implica o reconhecimento de que o poder do Estado (e por consequência as normas jurídicas) não decorre apenas do uso da força, mas também, e principalmente, da sua capacidade de se apresentar como poder legítimo, construindo, simbolicamente a sua legitimidade.

\subsection{Interdependência entre direito e política}

Afastada a hipótese cínica pelo reconhecimento da necessidade de o poder apresentar-se como legítimo através de instrumentos como o direito, a consequência é a admissão de que não há separação entre essas duas esferas da razão prática.

Disso decorrem algumas consequências às quais se deve atentar quando do exame de qualquer questão jurídica: quais os fatores políticos que deram origem às normas que são apresentadas como razões pelas partes? Qual o conflito de fundo que deu origem à demanda processual? ${ }^{76}$ Quais as consequências políticas da decisão judicial que resolveu o conflito ${ }^{77}$

Além disso, uma vez que se reconhece, não só o papel criativo do juiz, com a sua irredutibilidade racional (ainda que aplicado sob a aparência de racional e de submisso a critérios supostamente objetivos, como o princípio da proporcionalidade), como também a necessidade de superação do corte epistemológico que restringe o exame à justificação, é vital compreender que o exame das decisões judiciais passa tanto pelos seus aspectos políticos subjacentes quanto pela investigação dos padrões morais implícitos. Para isso, a análise "jurídica" deve ser ancorada a partir dos conhecimentos e análises de outros saberes, tais como Filosofia, Sociologia, Economia, Ciência Política, Antropologia, etc. ${ }^{78}$ Um exemplo

\footnotetext{
76 Para uma distinção entre lide sociológica e lide processual, confira-se: BACELLAR, Roberto Portugal. Juizados especiais: a nova mediação paraprocessual. São Paulo: RT, 2003, p. 220-223.

77 Confira-se, por exemplo, como o problema político e social dá o contorno de um instituto, a partir do estudo sobre a criação do mecanismo de emenda constitucional no processo constituinte norte-americano (VIEIRA, 1999, p. 61-68). Para uma leitura da processo histórico das Constituições brasileiras, confira-se, na mesma obra: VIEIRA, 1999, p. 114-130.

78 Assim, por exemplo, o estudo sobre a Justiça não pode partir do texto legal ou constitucional, mas sim da realidade social. Para o tema, confira-se: DIAS, Maria da Graça dos Santos. A Justiça e o Imaginário Social. Florianópolis: Momento Atual, 2003.
} 
deste tipo de observação transdisciplinar é apresentado por Lorea, juiz de direito e antropólogo, e com pesquisa de campo no Foro Central de Porto Alegre (RS) nos anos de 2001 a $2002,{ }^{79}$ que, em trabalho científico, pesquisou a hipótese de que os jurados representam uma visão leiga sobre a noção de justiça a ser aplicada no Júri.

Neste ponto, vale afastar o argumento da impossibilidade de exame das razões subjetivas que levaram à decisão. Com efeito, o fato de a interpretação ser um processo misterioso não impede a objetividade do direito e a sua observação lógica e científica, da mesma forma que o mistério sobre o processo de escolha das hipóteses pelos cientistas (abdução) não impede a verificação dos resultados colhidos por eles. ${ }^{80}$ Assim, por exemplo, Posner propõe que o direito possa ser avaliado a partir de objetivos mensuráveis que permitam aferir a performance das leis; por exemplo, uma lei de falências poderia ser observada quanto aos objetivos de reduzir o número de falências e a taxa de juros. Porém, ele reconhece que o Direito não está pronto para se comprometer desta forma, já que as regras jurídicas são, no geral, defendidas a partir de objetivos intangíveis de promoção geral (justiça, dignidade humana etc.), ainda que, na prática, eles impliquem consequências onerosas e imprevisíveis ou beneficiem categorias específicas (exemplo das empresas de transportes interessadas em decisões judiciais que determinam transporte de alunos para integração com escolas públicas). ${ }^{81}$

Desse modo, a título de exemplo, é possível indicar que a reformulação de leis processuais sobre o processo de execução civil não pode deixar de figurar critérios objetivos de avaliação dos seus resultados, comparando dados estatísticos anteriores e posteriores, tais como a duração média dos processos de execução, a proporção entre os valores executados e efetivamente cobrados etc.

Nesta obra, após ser estudada a concepção filosófica sobre a ideia de Justiça, a autora, com base em pesquisa de campo, aborda a prática e o imaginário social de comunidades faveladas, com entrevistas e análises que se utilizam dos métodos de pesquisa de campo comumente utilizados nas Ciências Sociais.

79 POSNER, 2007, p. 141.

${ }^{80}$ POSNER, 2007, p. 141.

${ }^{81}$ POSNER, 2007, p. 164-165. 


\subsection{O direito como prática moral e política de resolução de conflitos}

Talvez a conclusão mais importante seja a de que a rejeição à alienação do jurista e a aceitação de que a Constituição e as Leis são ferramentas construídas pelo homem (e não algo dado) implica aceitar que o direito é uma prática, e não um objeto.

Trata-se de conceituar o direito como uma prática moral e política de resolução de conflitos, que, nas sociedades ocidentais contemporâneas, ${ }^{82}$ se dá mediante argumentação. O direito é uma atividade de solução de conflitos que usa diversos materiais, tanto jurídicos quanto morais, econômicos e políticos, na proporção ditada a partir do apego determinado pelos valores dos juízes. Enquanto prática moral ${ }^{83}$ e política, o direito sujeita-se aos valores sociais e individuais presentes num determinado momento e espaço. Significa dizer que representam aspectos do direito tanto os julgamentos pelas ordálias na idade medieval quanto a aceitação de normas individuais arbitradas por tribunais internacionais contemporâneos.

Esse reconhecimento permite ampliar o âmbito da discussão e análise jurídica para além das fatores políticos envolvendo as partes (lide) ou legisladores (formação das leis), passando a abranger também os comportamentos, valores, embates políticos e crenças dos próprios atores do drama judicial, como juízes, advogados, promotores, jurados, auxiliares da justiça etc.

Aliás, é interessante notar que, para diferenciar sua teoria de um positivismo com regra secundária mais fluida, Dworkin diz, expressamente, que as decisões judiciais em casos difíceis não são decisões de

82 É importante não perder de vista que a aceitação da argumentação dita racional, sem utilização de preceitos divinos, ordálias ou outros fundamentos, dá-se em momento histórico recente e ainda não universalizado. Não existe nada que assegure a sua universalização e nem a sua permanência, senão a luta pela razão.

83 Esta proposição pode ser aplicada mesmo àqueles que, permanecendo formalistas ou positivistas extremados, entendem que o Direito não abrange considerações morais. É que, como bem destaca Posner, a atitude do juiz de submeter-se à autoridade da lei é uma atitude moral de obediência às regras, mas que ela é apenas uma dentre várias virtudes, e não se deve esquecer de outros valores. Para ele, a postura positivista "forte" representa uma obediência burocrática (POSNER, 2007, p. 187-188). A postura de dizer que as considerações éticas não são fontes apropriadas de obrigação jurídica a não ser que incorporadas pela lei é, ela mesma, uma atitude moral (POSNER, 2007, p. 186). 
direito e nem neutras. ${ }^{84}$ Por esse motivo, ele atribui ao direito uma função mais ampla daquela atribuída pelos positivistas.

Esta posição também é assumida por parcela dos teóricos ligados ao realismo jurídico. Posner, por exemplo, reconhece que o direito é uma atividade, vista a partir de uma teoria que fundamente a previsão das decisões dos juízes; para ele, nos casos difíceis, o direito não visa a uma resposta correta, mas razoável; os juízes não são reprodutores de decisões políticas anteriores, mas agentes responsáveis; o direito está ligado à ciência, mas não pode perder a ligação com a necessidade de coerção. ${ }^{85}$

Isso se concretiza em diversas formas. $\mathrm{Na}$ interpretação dos princípios, a compreensão do direito como prática moral e política deixa claro que, embora facilite a aplicação e previsão, os princípios e as regras regras escondem as discussões políticas e morais que precederam à gênese da lei e deram origem à norma. ${ }^{86}$

Apesar de defender a tese do direito como uma atividade, Posner entende que ela precisa ser aprimorada. Ela a aperfeiçoa por diversos motivos. Um deles é a necessidade de se reconhecer que os precedentes são "insumos" importantes, mas não exclusivos, pois haverá casos em que o juiz de instância inferior poderá acreditar que existem razões que levariam os tribunais superiores a tomarem outras decisões hoje que são diferentes das proferidas ontem. Outro motivo é que ela necessita de algum critério de avaliação para que possa ser normativa. Para Posner, por exemplo, a adição de algum tipo de jusnaturalismo fraco à teoria da previsão a tornaria melhor do que qualquer positivismo jurídico. ${ }^{87}$ Logo, a discussão se concentraria nos critérios de Justiça material usados como base para a aferição das razões apresentadas no conjunto de decisões judiciais. Assim, volta-se, consciente e diretamente, a discutir a efetividade de critérios materiais decorrentes da filosofia moral, tais como as teorias de justiça de Aristóteles, Rawls, Walzer etc.

\footnotetext{
${ }^{84}$ DWORKIN, 2002, p. 532-533.

85 POSNER, 2007, p. 37.

${ }^{86}$ POSNER, 2007, p. 63-64.

87 POSNER, 2007, p. 303-305.
} 


\subsection{O direito como (re)produtor de relações de poder}

Tendo o direito assumido o papel funcional de elemento estratégico de legitimação do poder que se consubstancia numa prática (que pode, ou não, ser racional e/ou argumentativa), tem-se, como consequência, o reconhecimento de que ele produz e reproduz relações de poder, seja físico (político), seja ideológico. Logo, a gramática jurídica tem que ser lida e traduzida a partir da perspectiva que explicite as relações de poder envolvidas, tanto de forma subjacente quanto no caso concreto.

A partir da obra de Foucault, o poder pode ser considerado como uma situação estratégica complexa numa sociedade que não representa uma única dominação maciça e homogênea de um grupo sobre outro, mas sim um de forma fragmentada nas múltiplas instâncias da vida, manifestando-se de formas sutis (como a criação e classificação de identidades ou o controle do corpo e dos desejos), ou expressas (como julgamentos e condenações). Segundo essa visão, o poder é uma forma múltipla de dominação que circula, pois funciona em cadeia, ou seja, o poder funciona e se exerce em rede, e os indivíduos estão sempre em posição de exercer o poder e de sofrer sua ação. ${ }^{88} \mathrm{O}$ poder é limitado por dois elementos; um formal (o direito) e outro como efeito do próprio poder (verdade). As relações de poder se manifestam e se estabelecem mediante criação, circulação e acumulação de discursos. ${ }^{89}$

Assim, o discurso do poder e sobre o poder deve ser investigado tanto no plano interno dos praticantes do direito ${ }^{90}$ quanto ao papel que eles exercer em com relação aos agentes externos e como condição de manutenção dos fatores de poder.

Com relação ao plano interno dos praticantes do direito, cogita-se sobre a necessidade de serem estudadas as relações de poder internas às instituições envolvidas na prática jurídica. Como são constituídas, alteradas

\footnotetext{
${ }^{88}$ FOUCAULT, Michel. Microfísica do poder. 10. ed. Rio de Janeiro: Graal, 1992, p. 160-162, 179-181, 183. WOLKMER, 2003, p. 76-77.

89 FOUCAULT, 1992, p. 179-180.

90 Isto é examinar, por exemplo, como, em sociedades concretas, é construído o saber pelos juízes, advogados, legisladores e doutrinadores, explicitando as condições estratégicas do seu atuar, e desvendar como são formadas as gramáticas de operação destes atores.
} 
e extintas as relações entre juízes, ${ }^{91}$ entre advogados (dentro da sua corporação), entre representantes do ministério público, e as relações entre eles. Não é possível, por exemplo, compreender a dinâmica dos processos dos juizados estaduais cíveis sem estudar as relações de poder que existem entre conciliadores, juízes leigos e juízes togados, assim como as relações entre o tribunal de justiça e os juízes que lhe se são subordinados. ${ }^{92}$ Trata-se de produzir, no campo do direito, a chamada dupla ruptura epistemológica, isto é, a reflexão sociológica sobre a própria reflexão produzida pelos cientistas sociais. ${ }^{93}$ É necessário discutir, por exemplo, como se dá, concretamente, a seleção e promoção de juízes e promotores.

${ }^{91}$ Para uma pequena amostra do potencial conflito latente entre as cortes superiores e a magistratura de primeira instância, confira-se a análise sobre a ADC no 1 (VIEIRA, 1999, p. 169-175, em especial p. 171).

${ }_{92}$ Para um estudo sobre o tema, confira-se VIANNA, Luiz Werneck et al. A judicialização da política e das relações sociais no Brasil. Rio de Janeiro: Revan, 1999. Nesta obra, descortina-se a judicialização da política pelo estudo de classificação, análise e estatística sobre a prática das ADIs no STF. Os autores também estudaram a prática dos Juizados Especiais Estaduais do Rio de Janeiro, descrevendo os atores sociais que participam das lides (incluindo as figuras dos conciliadores, juízes, leigos e outros), os tipos de lide real velada pela lide processual etc.

${ }^{93}$ Para o tema, confira-se a abordagem de SANTOS, Boaventura de Souza. Introdução a uma ciência pós-moderna. 3. ed. Rio de Janeiro: Graal, 1989. Nesta obra, dentre outras questões, ele aponta que, no estágio atual, em razão da concepção pragmática de verdade, a comunidade científica é um sistema aberto produzindo uma negociação do sentido e, por isso, há caráter provisório e retórico da verdade. É necessário, portanto, o resgate da retórica, com identificação dos auditórios e uso de discurso fundado também na analogia e nas paixões e no estudo do processo de negociação entre os grupos de cientistas, incluindo as relações de poder entre os grupos de cientistas e destes em relação aos demais grupos sociais, pois a comunidade científica faz o papel de mediação entre a ciência e a sociedade. Segundo ele, todo conhecimento é contextual, existindo quatro contextos (doméstico, trabalho, cidadania e mundialidade) com características específicas nos seguintes aspectos da unidade da prática social, a forma institucional, o mecanismo de poder, a forma de direito e o modo de racionalidade. Esta concepção afasta-se da de Habermas porque não se restringe ao consenso, mas abrange, também, o conflito e as tensões latentes. Por tudo isso, a aplicação técnica (chamada de aplicação edificante) dos conhecimentos tem que observar certas características, dentre elas: a) a aplicação é concreta e tem que estar comprometida com o seu impacto social; b) os fins só se concretizam quando se discute os meios; (c) a aplicação é processo argumentativo entre os grupos que lutam pela decisão do conflito; d) o know-how técnico tem sentido dado pelo know-how ético; e) é comprometida com o mais fraco; f) o novo conflito interno da ciência é entre aplicação técnica e aplicação edificante. 
Quanto ao papel que exercem em relação aos agentes externos e como condição de manutenção dos fatores de poder, ao incorporar elementos do realismo jurídico, incluindo as correntes da AED e CLS, deve-se estudar o direito realmente aplicado pelos tribunais e suas relações com a instituição, manutenção ou transformação das relações de poder.

Neste aspecto, vale a lembrança de Foucault:

[...] Recapitulando as cinco precauções metodológicas: em vez de orientar a pesquisa sobre o poder no sentido do edifício jurídico da soberania, dos aparelhos de Estado e das ideologias que o acompanham, deve-se orientá-la para a dominação, os operadores materiais, as formas de sujeição, os usos e as conexões da sujeição pelos sistemas locais e os dispositivos estratégicos. É preciso estudar o poder colocando-se fora do modelo do Leviatã, fora do campo delimitado pela soberania jurídica e pela instituição estatal. É preciso estudá-lo a partir das técnicas e táticas de dominação. ${ }^{94}$

O seu estudo sobre o Poder parte de algumas premissas metodológicas: 1) observar a extremidade do poder, ou seja, onde ele é aplicado (instituições que aplicam as punições) e não onde haveria a sua legitimação (rei ou governante); 2) estudar a prática real e efetiva do poder (face externa) e não a sua intenção (face interna); 3) compreender o poder não como algo que um indivíduo ou grupo têm contra outro ou outros, mas sim como algo que circula e funciona em cadeia; 4) a análise tem que ser ascendente, e não dedutiva, ou seja, parte-se do exame dos históricos dos mecanismos, técnicas e instrumentos de poder, em vez de iniciar mediante deduções decorrentes do fenômeno geral da dominação por uma classe e 5) o poder é formado na base a partir de instrumentos sutis e reais de formação e acumulação de saber (métodos de observação, registro, inquérito e pesquisa e aparelhos de verificação) que produzem a ideologia, e não o inverso. ${ }^{95}$

\subsection{Um realismo jurídico à brasileira.}

A dogmática constitucionalista brasileira, para estar atenta às relações entre direito, política e moral, deve apreender não apenas o que

94 FOUCAULT, 1992, p. 186.

95 FOUCAULT, 1992, p. 181-187 
foi dito, mas também o que foi feito, isto é, a prática das decisões e a sua efetivação, influenciando-se, assim, em escolas teóricas derivadas do realismo jurídico. ${ }^{96}$

O realismo jurídico é a corrente da filosofia do direito que identifica como direito válido somente aquele que é realmente eficaz, sem levar em consideração o que a norma diz, mas sim o que é efetivamente praticado pelos juízes. ${ }^{97}$ Opõe-se ao positivismo jurídico, ao jusnaturalismo e ao idealismo jurídico. O realismo jurídico assumiu várias formas. Uma das divisões mais citadas é a que distingue o realismo norte-americano (Gray, Holmes, Llevellyn e Loyd) e o realismo escandinavo (Hägerström, Lundstedt, Ross). ${ }^{98} \mathrm{O}$ realismo americano abriga várias formas, dentre elas o Critical Legal Studies e a Análise Econômica do Direito. ${ }^{99}$ Para Posner, enquanto o Critical Legal Studies veem o Direito como Política, a Escola do Direito e Economia o veem como Economia; porém, ambos assemelham-se ao buscarem suas fontes fora do espectro jurídico. ${ }^{100}$

Ross formula uma versão eclética, dizendo que sua teoria busca a consistência e a previsibilidade no comportamento verbal externo dos juízes, e também psicológica por entender que estes comportamentos decorrem de significados e motivações oriundas da ideologia normativa dos juízes. ${ }^{101}$ Segundo ele, o Direito é uma expressão linguística diretiva, isto é, sem significado representativo, mas com intenção de exercer

96 Vide quadro baseado em WARAT, Luiz Alberto. Introdução geral ao direito, p. 61:

\begin{tabular}{|l|l|l|}
\hline \multicolumn{1}{|c|}{ Item } & \multicolumn{1}{c|}{ Comparação Realismo vs. Positivismo/dogmática jurídica } \\
\hline Linguagem do direito: & Linguagem natural e, portanto, vaga e ambígua. & \multicolumn{1}{c|}{ Linguagem lógico-formal e, portanto, precisa. } \\
\hline Fonte do direito: & $\begin{array}{l}\text { As fontes são os motivos determinantes das } \\
\text { decisões judiciais. }\end{array}$ & A única fonte é a lei. \\
\hline Papel do juiz: & Constitutivo, mediante ato de vontade. & Mecânico, mediante ato de conhecimento. \\
\hline Valor prevalente: & Equidade. & Segurança. \\
\hline $\begin{array}{l}\text { Objeto da Ciência } \\
\text { Jurídica: }\end{array}$ & $\begin{array}{l}\text { Argumentos dos órgãos judiciais. Funda-se no } \\
\text { positivismo lógico. }\end{array}$ & Direito positivado. \\
\hline $\begin{array}{l}\text { Estrutura do raciocínio } \\
\text { jurídico: }\end{array}$ & Silogismo retórico. & Silogismo demonstrativo (subsunção). \\
\hline
\end{tabular}

97 SILVA, Moacyr Motta da. Direito, justiça, virtude moral e razão: reflexões. Curitiba: Juruá, 2003, p. 24. LUMIA, Giuseppe. Elementos de teoria e ideologia do direito. São Paulo: Martins Fontes, 2003, p. 177.

98 SILVA, 2003, p. 24.

99 FARALLI, 2006, p. 31; POSNER, 2007, p. 590.

${ }^{100}$ POSNER, 2007, p. 590-591.

${ }^{101}$ ROSS, 2003, p. 100. 
influência a fim de dirigir pessoas (juízes e cidadãos) a agirem de uma certa maneira. ${ }^{102}$ Ao se afastar da metafísica, Ross define direito vigente como "o conjunto abstrato de idéias normativas que serve como um esquema interpretativo para os fenômenos do direito em ação, o que, por sua vez significa que essas normas são efetivamente acatadas e que o são porque são experimentadas e sentidas como socialmente obrigatórias". ${ }^{103}$

Ross afirma que sua perspectiva para a ciência do direito ligase necessariamente à ideologia; segundo ele, é necessária a atenção da Ciência do Direito pelo mundo da vida social, já que o juiz não é motivado exclusivamente pelas normas jurídicas, mas também pelos fins sociais. Por isso, defende que não existe uma fronteira nítida entre Ciência do Direito e Sociologia do Direito, mas sim uma relativa diferença de abordagem. ${ }^{104}$

O "Critical legal studies" (CLS), por sua vez, retoma as teorias de Marx, o realismo americano e o desconstrutivismo de Derrida, e, entre os anos 1970 e 1980, desenvolveu a concepção de que o direito não é racional ou justo, mas sim arbitrário, historicamente condicionado para exercer a função de cumprir fins políticos e econômicos do liberalismo. ${ }^{105}$ Para o CLS, o direito é política ${ }^{106}$ ou política e ideologia. ${ }^{107}$ Os principais teóricos do CLS, influenciados pelo realismo jurídico, apontam a indeterminação jurídica como a insuficiência dos argumentos jurídicos para a previsão da solução para uma determinada questão. ${ }^{108}$

Como método de análise, o CLS desenvolve um procedimento em três etapas: 1) trashing (desbastar), consistente no desmascaramento da mensagem política implícita no discurso jurídico, revelando a sua ideologia que está por detrás e suas contradições; 2) desconstrução, na qual se revela a estrutura de conflito, presente no liberalismo, entre indivíduo e comunidade (individualismo versus altruísmo); e 3) análise histórica ou

\footnotetext{
102 ROSS, 2003, p. 28-31.

${ }^{103}$ ROSS, 2003, p. 41.

${ }^{104}$ ROSS, 2003, p. 43.

${ }^{105}$ FARALLI, 2006, p. 32-33; GODOY, Arnaldo Sampaio de Moraes. Introdução ao movimento Critical Legal Studies. Porto Alegre: Sergio Antonio Fabris, 2005, p. 9-12.

${ }^{106}$ POSNER, 2007, p. 206.

${ }^{107}$ GODOY, 2005, p. 13.

${ }^{108}$ GODOY, 2005, p. 9-15.
} 
genealógica, na qual se reconstrói a história das ideias jurídicas, revelando como elas se justificam no contexto social em que nascem. ${ }^{109}$

Outra corrente teórica, incipiente no Brasil, é a Análise Econômica do Direito - AED ("Law and Economics"). Com influências do utilitarismo, da filosofia pragmática e da análise econômica, a AED é uma teoria que, evitando a metafísica abstrata, privilegia as consequências previsíveis cujos efeitos econômicos sejam mais benéficos para o sistema (indivíduos e comunidade), maximizando a riqueza num juízo de custo/ benefício, ainda que de forma contrária aos precedentes. ${ }^{110}$ Segundo Posner, a Análise Econômica do Direito (AED) é um ramo da Economia, e, por isso, é uma ciência. ${ }^{111}$

Pela AED, mesmo quando os juízes acreditam estar realizando senso de justiça ou de racionalidade, eles estão, no fundo, maximizando a riqueza. ${ }^{12}$ Por isso, é necessário que o juiz não esteja estritamente obrigado a julgar de acordo com precedentes, mas seja livre para decidir a partir dos cálculos de custos e benefícios. ${ }^{113} \mathrm{O}$ direito não é um conjunto de regras dadas ou uma série de soluções pré-fabricadas, mas sim um conjunto de atividades dos juízes e advogados destinadas a resolver casos jurídicos reais, e de soluções efetivas dadas a problemas jurídicos concretos. ${ }^{114}$ Assim, para Posner, o fato de a interpretação ser um processo misterioso não impede a objetividade do direito e a sua observação lógica e científica, da mesma forma que o mistério sobre o processo de escolha das hipóteses pelos cientistas (abdução) não impede a verificação dos resultados colhidos por eles. ${ }^{115}$

\subsection{Uma proposta de modelo teórico para um novo Constitucionalismo}

Um dos passos mais importantes para uma compreensão transformadora do direito é a incorporação dos elementos citados - política,

\footnotetext{
${ }^{109}$ FARALLI, 2006, p. 32-33.

${ }^{110}$ FARALLI, 2006, p. 35-37.

111 POSNER, 2007, p. 85.

${ }^{112}$ FARALLI, 2006, p. 36.

${ }^{113}$ FARALLI, 2006, p. 37.

${ }^{114}$ FARALLI, 2006, p. 37.

115 POSNER, 2007, p. 141.
} 
economia etc. - com influência do realismo jurídico, que pode ser feita a partir de uma extensão do modelo teórico proposto por Atienza em uma de suas últimas obras, "mediante inclusão de uma quarta camada referente ao poder". ${ }^{116}$

$\mathrm{Na}$ obra "El derecho como argumentación", Atienza elabora um projeto de construção de uma teoria argumentativa do direito, estruturando uma concepção argumentativa a partir de três planos, aparentemente influenciado pela Filosofia da Linguagem e seus três campos (sintaxe, semântica e pragmática). Ele defende que a argumentação pode se dar em três dimensões, cada uma delas ligada preponderantemente a um tipo de contexto ou problema a que busca resolver. ${ }^{117}$

A primeira concepção é a formal. Refere-se a problemas lógicos ou matemáticos nos quais a solução consiste em apresentar regras de inferência dedutiva que autorizam conclusões a partir de certas premissas. Estes problemas, em certo sentido, não têm a ver com a realidade, requerendo abstração de como é o mundo. ${ }^{118}$ A ênfase na concepção formal é dada ao

${ }^{116}$ Ao analisar a polêmica entre Hart e Dworkin, Atienza não só assume a possibilidade de o positivismo incorporar os princípios de justiça e os valores morais pela regra de reconhecimento, como também afirma a imbricação entre direito e moral ao dizer que "la tesis de la discricionalidad presupone la de la separación entre el Derecho y la moral, y con ella la de la negación de la unidad de la razón práctica [...] lleva [...] a ver el Derecho esencialmente como un objeto de conocimiento". Para ele, a teoria do direito como argumentação afasta-se do positivismo jurídico porque vê o direito como atividade composta por fases da sua prática social (e não como uma realidade dada e formada por um conjunto de normas) e por observar que o Direito não é neutro, mas sim uma realização da argumentação que funde a teoria com a prática (ATIENZA, Manuel. El derecho como argumentación. Barcelona: Ariel, 2006, p. 31-33). Em trecho posterior, ele assume, claramente, a posição de que as normas jurídicas têm que possuir um substrato moral, afirmando que "El que la justificación jurídica tenga siempre, en último término, un carácter moral y que, por lo tanto, las razones jurídicas estén sometidas a las morales, depende de un principio básico del razonamiento práctico, a saber, que se trata de un razonamiento unitario lo cual impiede su desintegración y hace posible que cumpla su función básica de dirimir conflictos prácticos. [...] un objetivismo moral mínimo es una condición necesaria para dar sentido a la argumentación judicial y, en general, a la argumentación jurídica. O sea, si toda justificación jurídica (judicial, legislativa, etc.) es en el último término (o presupone) una justificación moral, entonces, si no fuera posible una justificación moral en sentido estricto (si los juicios morales no contuviesen una pretensión - objetiva - de corrección), tampouco sería posible la justificación jurídica " (ATIENZA, 2006, p. 246)

117 ATIENZA, 2006, p. 77/80.

118 ATIENZA, 2006, p. 80. 
aspecto sintático da linguagem e à noção de inferência; não é, portanto, a verdade ou correção das premissas, mas sim um esquema formal que permite justificar os passos tomados a partir delas para chegar na conclusão. Por isso, o centro da concepção formal é a lógica dedutiva. ${ }^{119}$ Após discorrer sobre alguns dos diversos tipos de lógicas, Atienza conclui que a lógica possui diversas limitações. Uma delas é que ela não trata dos argumentos, mas sim dos esquemas dos argumentos. Outra é que a lógica, por si só, não permite justificar, explicar, ou prever nada. Alguns esquemas lógicos, como a lógica dedutiva, não são adequados para os argumentos jurídicos, que exigem instrumentos como lógicas deônticas e/ou divergentes para representar a argumentação dos juízes. ${ }^{120}$ Apesar disso, Atienza pondera que, à semelhança do que faz a gramática para a linguagem, a lógica traz diversas contribuições: 1) oferece esquemas e formas de argumentação que ajudam a organizar os argumentos; 2) auxilia na contextualização dos argumentos por fornecerem uma linguagem formal que traduz a linguagem natural; e 3) proporciona critérios para controle dos argumentos. ${ }^{121}$

A segunda dimensão ou concepção é a material, na qual as premissas e a conclusão são os enunciados interpretados, ou seja, aceitos por quem argumenta como corretos; o centro dela, portanto, são as premissas e a conclusão, e não o processo de inferência desta a partir daquelas. ${ }^{122}$ A concepção material de argumentação é aquela que não se abstrai de levar em conta o conteúdo dos argumentos e o contexto em que eles são realizados. Leva em conta a verdade ou correção das premissas e da conclusão. Por isso, considera os elementos materiais para analisálos em termos gerais e sistemáticos. ${ }^{123}$ Contudo, essa concepção não é simplesmente um estudo empírico de argumentos concretos, mas sim um estudo sistemático das classes de argumentos. Usa, para isso, um método que permite captar a forma e a estrutura da inferência. Investiga o que torna uma razão hábil a justificar uma posição, quais são os tipos de boas razões que existem e como elas operam no contexto de diversas práticas discursivas, como a ética e o direito. ${ }^{124}$

\footnotetext{
${ }^{119}$ ATIENZA, 2006, p. 89-90.

${ }^{120}$ ATIENZA, 2006, p. 176-177.

${ }^{121}$ ATIENZA, 2006, p. 179-180.

${ }^{122}$ ATIENZA, 2006, p. 91.

${ }^{123}$ ATIENZA, 2006, p. 182.

${ }^{124}$ ATIENZA, 2006, p. 183.
} 
A terceira e última concepção é a pragmática, na qual os enunciados não são interpretados ou indagados quanto à sua veracidade, mas sim postos em discussão quanto à sua aceitação. Esta dimensão abriga dois planos: o da Dialética e o da Retórica. Na dialética, o problema consiste essencialmente nos esquemas procedimentais que regem o debate; na retórica, o que importa são as regras técnicas com as quais um orador pode convencer. ${ }^{125}$

A argumentação jurídica não obedece somente a uma dessas concepções puras, mas sim a combinações delas, não se podendo prescindir de nenhuma. ${ }^{126}$ Em alguns contextos, uma determinada concepção pode sobressair; assim, por exemplo, a Dialética pode ser utilizada pelos advogados, a formal para alguns trabalhos teóricos de doutrina e a material para as sentenças dos juízes. ${ }^{127}$ A questão principal para Atienza é saber como combinar esses ingredientes das três concepções no estudo das argumentações de forma a desenvolver uma teoria plena da argumentação jurídica. ${ }^{128}$

Sugere-se, então, a criação de uma quarta camada ou concepção, na qual os enunciados são investigados a partir da sua relação com o Poder, usando métodos de outras ciências (economia, política, sociologia, antropologia) ou saberes (filosofia). Uma possibilidade, a partir da rejeição da hipótese cínica, é contrapor a realidade das decisões jurídicas com as pretensões normativas das Teorias de Justiça desenvolvidas pela Filosofia, tais como a de Rawls, Walzer, Kolm ou outros. ${ }^{129}$

Nesta camada, poder-se-ia cogitar da aferição segundo as consequências observáveis das decisões jurídicas. Esta abordagem é defendida por Posner, para quem é impossível formar um consenso exato sobre uma objetividade da interpretação jurídica, pois as regras jurídicas são indeterminadas e servem apenas como diretrizes para os juízes, que usam tanto as regras legais e jurisprudenciais quanto suas preferências políticas e morais. ${ }^{130}$ Esta abordagem pragmática do direito sustenta-se nas seguintes

\footnotetext{
${ }^{125}$ ATIENZA, 2006, p. 92-94.

${ }^{126}$ ATIENZA, 2006, p. 94-95.

${ }^{127}$ ATIENZA, 2006, p. 97-98.

128 ATIENZA, 2006, p. 98-99.

${ }^{129}$ Para o tema: BOLLMANN, 2007.

${ }^{130}$ POSNER, 2007, p. 608-612.
} 
teses: 1) não existe um raciocínio jurídico, mas sim razão prática que usa a lógica e outros métodos; 2) é impossível demonstrar que uma decisão jurídica é correta, pois os métodos de interpretação jurídica não seguem uma metarregra; 3) a solução de casos difíceis não é objetiva; 4) as mudanças no direito não decorrem de forma racional; 5) o direito é uma atividade, e não um conceito ou um conjunto de conceitos reais ou decorrentes de uma moral de direito natural; 6) não há sentido útil em abordar o direito de forma interpretativa, pois não existem interpretações logicamente corretas; 7) não existem conceitos de justiça que possam ser usados como forma de resolver os problemas jurídicos; 8) o direito é funcional, ou seja, pode ser avaliado a partir dos seus efeitos de alocação social dos recursos. ${ }^{131}$

Segundo Atienza, a Teoria Padrão de Argumentação necessita incorporar conteúdos de natureza moral e política para que possa fornecer critérios de correção ou escolha da decisão; ou seja, é necessário incluir teorias da equidade, discricionariedade e razoabilidade, pois a racionalidade prática, por si só, não consegue indicar qual delas é a mais correta, mas apenas que elas são racionalmente adequadas. ${ }^{132}$

Esta quarta camada serviria, então, como o elo de infiltração dos outros saberes dentro da produção teórica jurídica.

\section{Conclusão}

A partir do texto apresentado, é possível traçar algumas premissas que, embora não conclusivas no sentido de uma verdade inalcançável, permitem supor que o problema não é o modelo pós-positivista ou neoconstitucionalista, mas a sua insuficiência. A simples exposição das razões não permite, por si só, a avaliação racional das decisões, sendo necessário vencer o corte epistemológico para incluir uma análise das motivações. Isso só pode ser feito analisando-se a prática jurídica como um todo a partir das ferramentas de outros saberes.

Compreende-se, então, que o fireito é prática moral e política e, por isso, deve ser examinado a partir de aportes de outros ramos das ciências, combinadas com aspectos da filosofia.

${ }^{131}$ POSNER, 2007, p. 613-616.

${ }^{132}$ ATIENZA, 2006, p. 222-223. 
Isso requer o aporte teórico de um realismo jurídico à brasileira que pode ser implementado com uma extensão da Teoria do Direito de Atienza como argumentação.

Caso contrário, a prática neoconstitucionalista pode produzir um aumento do ativismo judicial, que, no Brasil, diante da concentração de poder e atribuições numa única Corte (STF), pode, no limite, permitir o uso retórico de argumentos abertos, gerando uma má política disfarçada de prática democrática. Juízes, promotores, advogados e cientistas podem ser tão ruins quanto os ditadores; logo, atribuir-lhes poderes sem instrumentos de controle significa um passo num rumo indesejável, ainda que inconsciente e orientado de boa-fé. As boas intenções dos póspositivistas (implementar direitos sociais previstos nas Constituições) pode levar ao enfraquecimento da democracia e à utilização estratégica do Judiciário por parte de grupos organizados.

Somente a explicitação dos valores embutidos nas decisões judiciais pode levar a uma análise política e moral do Direito, que necessariamente decorre de uma declaração e vontade do julgador. Incluir esta discussão de forma clara e analítica impede que se faça o que não se diz e não se diga o que se faz.

\section{Referências}

ALEXY, Robert. Teoria da argumentação jurídica: a teoria do discurso racional como teoria da fundamentação jurídica. 2. ed. Tradução de Zilda Hutchinson Schild Silva. Revisão técnica de Cláudia Toledo. São Paulo: Landy, 2005.

ALEXY, Robert. Teoria de los derechos fundamentales. Madrid: Centro de Estúdios Políticos y constitucionales, 2002. 607 p.

ALVES, Alaôr Caffé. Apresentação. In: ROSS, Alf. Direito e justiça. Bauru: EDIPRO, 2003.

ATIENZA, Manuel. As razões do direito: teorias da Argumentação Jurídica. 3. ed. Trad. Maria Cristina Guimarães Cupertino. São Paulo: Landy, 2003.

ATIENZA, Manuel. El derecho como argumentación. Barcelona: Ariel, 2006. 
BACELLAR, Roberto Portugal. Juizados especiais: a nova mediação paraprocessual. São Paulo: RT, 2003.

BARCELLOS, Ana Paula de. A eficácia jurídica dos princípios constitucionais: o princípio da dignidade humana. Rio de Janeiro: Renovar, 2002.

BARCELLOS, Ana Paula de. Neoconstitucionalismo, Direitos Fundamentais e Controle de Políticas Públicas. Revista de direito administrativo, v. 240, abr./jun. 2005, p. 83-103.

BARROSO, Luís Roberto. Interpretação e aplicação da constituição: fundamentos de uma dogmática constitucional transformadora. 3. ed. rev. e atual. São Paulo: Saraiva, 1999.

BOLLMANN, Vilian. Princípios de Seguridade Social: o direito previdenciário no Brasil sob o enfoque da Teoria da Justiça de Aristóteles. 2007. 133p. Dissertação (Mestrado em Ciência Jurídica) Universidade do Vale do Itajaí, Itajaí, 2007.

BOLLMANN, Vilian. Políticas públicas, direitos fundamentais e os limites da atuação do Poder Judiciário. In: VAZ, Paulo Afonso BRUM; SCHÄFER, Jairo Gilberto (Org.). Curso modular de direito constitucional. Florianópolis: Conceito Editorial, 2008.

BONAVIDES, Paulo. Curso de Direito Constitucional. 11. ed. São Paulo: Malheiros, 2001. 797 p.

BRASIL. Justiça Federal. Juizado Especial Federal Cível de Jaraguá do Sul. Processo no 2008.72.59.000678-7. Sentença. Juiz Emmerson Gazda. Autor: Adriane Marina Zilsdorff Finger. Réus: União, Município de Jaraguá do Sul e Estado de Santa Catarina. Julgada em 04/12/2008. Disponível em: $<$ https://jef.jfsc.gov.br/eproc/consulta_processo_ eproc_nova.php?num_processo_consulta=200872590006787\&chave_ consulta $1=\&$ chave_consulta $2=\&$ chave_consulta3 $=>$. Acesso em: $15 \mathrm{dez}$. 2008.

BRASIL. Supremo Tribunal Federal. Medida Cautelar em Ação Direta de Inconstitucionalidade 1480. Confederação Nacional do Transporte e Confederação Nacional da Indústria. Presidente da República e Congresso Nacional. Relator: Celso de Mello. Julgado em 04/09/1997, DJ 18/05/2001, p. 429, ement. 2031/213. 
CALDERA, Alejandro Serrano. Razão, direito e poder: reflexões sobre a democracia e a política. Ijuí: Unijuí, 2005.

CAMARGO, Margarida Maria Lacombe. Hermenêutica e Argumentação: uma contribuição ao Estudo do Direito. 3. ed. ver. atual. Rio de Janeiro: Renovar, 2003. 294p.

CANOTILHO, José Joaquim Gomes. Direito constitucional e teoria da constituição. 4. ed. Coimbra: Almedina, 1999. 1.462 p.

CHAUÍ, Marilena. Convite à filosofia. São Paulo: Ática, 1997.

DIAS, Maria da Graça dos Santos. A Justiça e o Imaginário Social. Florianópolis: Momento Atual, 2003.

DUTRA, Delamar José Volpato. Razão e consenso em Habermas: a teoria discursiva da verdade, da moral, do direito e da biotecnologia. Florianópolis: Editora da UFSC, 2005.

DWORKIN, Ronald. O império do direito. São Paulo: Martins Fontes, 1999. 513p.

DWORKIN, Ronald. Levando os Direitos a sério. São Paulo: Martins Fontes, 2002. 568p.

DWORKIN, Ronald. Uma questão de princípio. 2. ed. São Paulo: Martins Fontes, 2005. 593p.

ESPÍNDOLA, Ruy Samuel. Conceito de princípios constitucionais: elementos teóricos para uma formulação dogmática constitucionalmente adequada. São Paulo: RT, 1999. 274p.

FARALLI, Carla. A filosofia contemporânea do direito: temas e desafios. Tradução de Candice Premaor Gullo. São Paulo: Martins Fontes, 2006.

FOUCAULT, Michel. Microfísica do poder. 10. ed. Rio de Janeiro: Graal, 1992.

GHIRALDELLI JÚNIOR, Paulo. Caminhos da filosofia. Rio de Janeiro: DP\&A, 2005.

GODOY, Arnaldo Sampaio de Moraes. Introdução ao movimento Critical Legal Studies. Porto Alegre: Sergio Antonio Fabris, 2005. 
HABERMAS, Jürgen. Direito e democracia: entre facticidade e validade. Tradução de Flávio Beno Siebeneichler. Rio de Janeiro: Tempo Brasileiro, 1999.

LASSALE, Ferdinand. A essência da Constituição. 5. ed. Rio de Janeiro: Lúmen Júris, 2002.

LOREA, Roberto Arriada. O Tribunal do Júri de Porto Alegre: um estudo antropológico. Revista AJURIS, n. 93, mar. 2004, p. 247-287.

LUMIA, Giuseppe. Elementos de teoria e ideologia do direito. São Paulo: Martins Fontes, 2003.

MARCONDES, Danilo. Filosofia analítica. Rio de Janeiro: Jorge Zahar ed., 2004.

MARCONDES, Danilo. A pragmática na filosofia contemporânea. Rio de Janeiro: Jorge Zahar ed., 2005a.

MARCONDES, Danilo. Iniciação à história da filosofia. 9. ed. Rio de Janeiro: Jorge Zahar Ed., 2005b.

MARÍAS, Julián. História da filosofia. São Paulo: Martins Fontes, 2004.

MELO, Osvaldo Ferreira de. Fundamentos da política jurídica. Porto Alegre: Sergio Antonio Fabris Editor, 1994.

POSNER, Richard. Problemas de filosofia do direito. Tradução de Jefferson Luiz Camargo. Revisão Técnica Mariana Mota Prado. São Paulo: Martins Fontes, 2007.

RAWLS, John. Uma teoria da justiça. 2. ed. Tradução de Almiro Pisetta e Lenita Maria Rímoli Esteves. São Paulo: Martins Fontes, 2002.

ROSS, Alf. Direito e justiça. Tradução de Edson Bini. Bauru: EDIPRO, 2003.

SANTOS, Boaventura de Souza. Introdução a uma ciência pós-moderna. 3. ed. Rio de Janeiro: Graal, 1989.

SILVA, Luís Virgílio Afonso da. O proporcional e o razoável. Revista dos Tribunais, ano 91, v. 798, abr. 2002. p. 23-50.

SILVA, Moacyr Motta da. Direito, justiça, virtude moral e razão: reflexões. Curitiba: Juruá, 2003. 
STRECK, Lênio Luiz. Hermenêutica jurídica e $(m)$ crise: uma exploração hermenêutica da construção do Direito. 5. ed. Porto Alegre: Livraria do Advogado, 2004.

TOULMIN, Stephen Edelston. Os usos do argumento. Tradução de Reinaldo Guarany. 2. ed. São Paulo: Martins Fontes, 2006.

VIANNA, Luiz Werneck; REZENDE DE CARVALHO, Maria Alice; MELO, Manuel Palácios Cunha; BURGOS, Marcelo Baumann. A judicialização da política e das relações sociais no Brasil. Rio de Janeiro: Revan, 1999.

VIEIRA, Oscar Vilhena. A Constituição e sua reserva de Justiça: um ensaio sobre os limites matérias ao poder de reforma. São Paulo: Malheiros, 1999.

WOLKMER, Antônio Carlos. Ideologia, Estado e Direito. 4. ed. São Paulo: Revista dos Tribunais, 2003.

ZAGREBELSKY, Gustavo. El derecho dúctil: ley, derechos, justicia. Trad. Marina Gascón. Trotta: Madrid, 2005. 